PAA 33-13
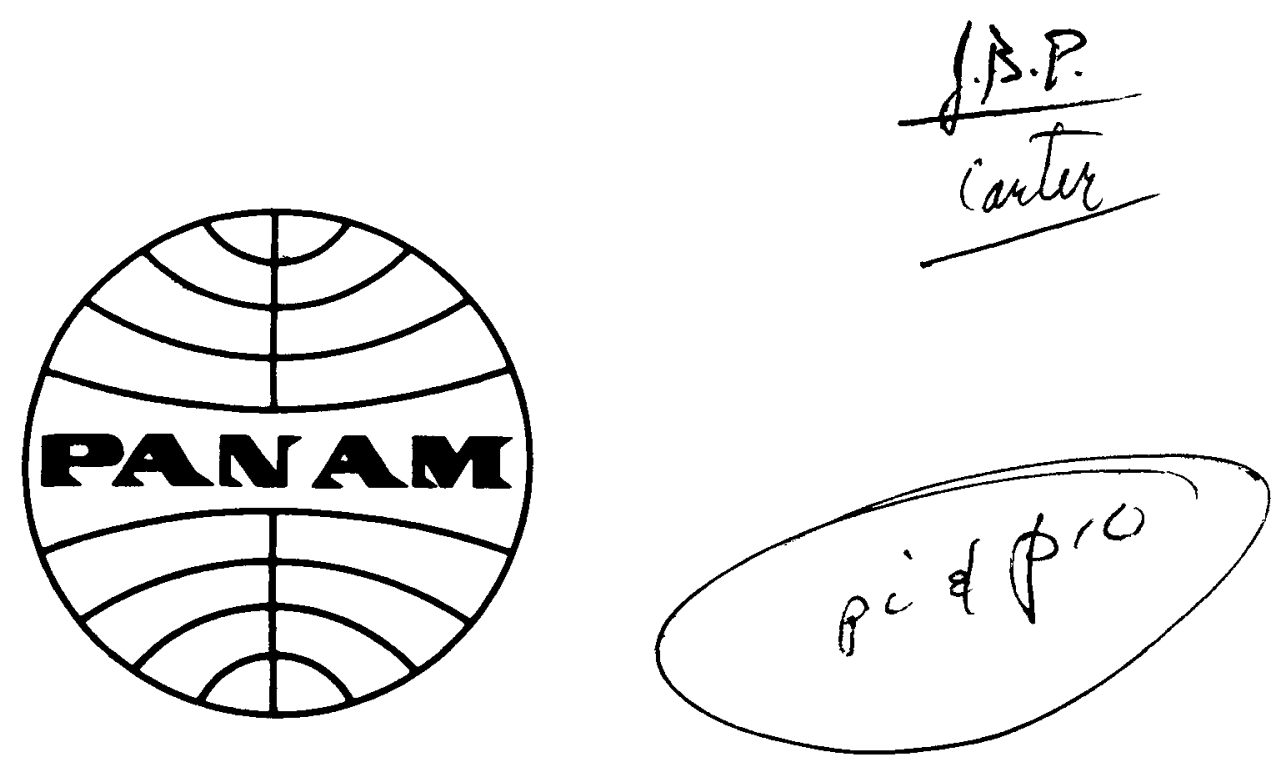

\title{
ON SITE RADIOLOGICAL REPORT FOR THE PHOEBUS IB REACTOR TEST SERIES
}

\section{MASTER}

\section{SPACE NUCLEAR PROPULSION OFFICE NEVADA EXTENSION}

PREPARED BY

PAN AMERICAN WORLD AIRWAYS

NRDS PROJECT

CONTRACT SNPN-5

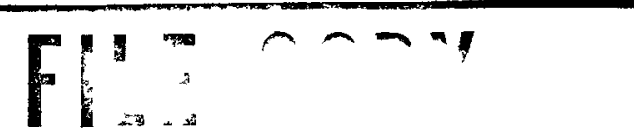

lis.

Technical Documeni C.....
DISTRIBUTION OF THIS DOCUMENT UNLIMITED

TECHNICAL DOCUMENT CENTER Nuclear Rocket Operations

DOC. NO. 


\section{DISCLAIMER}

This report was prepared as an account of work sponsored by an agency of the United States Government. Neither the United States Government nor any agency Thereof, nor any of their employees, makes any warranty, express or implied, or assumes any legal liability or responsibility for the accuracy, completeness, or usefulness of any information, apparatus, product, or process disclosed, or represents that its use would not infringe privately owned rights. Reference herein to any specific commercial product, process, or service by trade name, trademark, manufacturer, or otherwise does not necessarily constitute or imply its endorsement, recommendation, or favoring by the United States Government or any agency thereof. The views and opinions of authors expressed herein do not necessarily state or reflect those of the United States Government or any agency thereof. 


\section{DISCLAIMER}

Portions of this document may be illegible in electronic image products. Images are produced from the best available original document. 
Report No: PAA 33-13

Is sued: August 18, 1967

ON SITE

RADIOLOGICAL REPORT

FOR THE

PHOEBUS IB REACTOR TEST SERIES

Approved by:
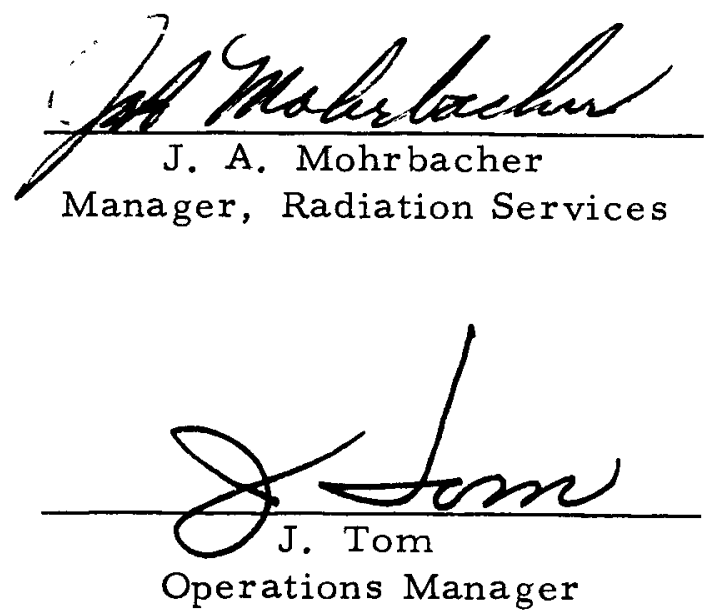

This report was poTICE

sponsored by the prepared as an account of work

the United the United States Government. Neither

Research States nor the United States Energy

Research and Development Administration, nor any of

their employees, nor any of their, nor any of

subcontractors, or their of their contractors,

warranty, express or imple employees, makes any

liability or responsibility implied, or assumes any legal

or usefulness of any inform the accuracy, completeness

process disclosed, or

infringe privately owned rights.

PAN AMERICAN WORLD AIRWAYS, INC.

Nuclear Rocket Development Station Project

Las Vegas, Nevada 
Radiological support for the Phoebus IB reactor test series was conducted essentially according to pre-test plans. The radiation levels at the Control Point during powered operations were a factor of 16 less than on previous full powered runs, resulting from the use of the reactor shield.

Although the hot line for EP-IV was along the five degrees azimuth from the Cell, changing wind conditions attendant with pulse cooling preduced on - site contamination at all populated facilities except E-MAD and ETS-1. The maximum particle concentration at any facility was 120 particles per 100 square feet at $R-M A D$.

Five per cent of 4, 100 contamination checks indicated contamination on personnel or their clothing up to an uncorrected radiation level of $200 \mathrm{mR} / \mathrm{hr}$ beta-gamma. Decontamination to within the guides, which were increased on run night and the next day, was successful for all skin contamination incidents and for most clothing contamination cases.

A discrete particle was detected on each of two individuals. The assigned dose for the one with the particle on his left cheek was $30.4 \mathrm{rads}$ to the volume of tissue having a surface area of one square centimeter surrounding the particle. The dose assignment for the lens of his left eye was calculated to be $415+207$ mrads. The localized dose for the second individual was 4.9 rads to the volume of tissue having a surface area of one square centimeter surrounding the particle on his right forearm.

The total radiation exposure received at Test Cell " $\mathrm{C}$ " was $112.5 \mathrm{R}$ during the period from EP-I until the end of March. The maximum individual cumulative exposure was 2.02 R. The majox Test Cell decontamination efforts accounted for $80 \mathrm{R}$ of exposure, took about one month, and required the expenditure of $\$ 98,100$, which included 5,550 manhours.

Positive activities of non-natural-occurring radioisotopes were detected in 19 individuals out of the 61 who were subjected to whole body counting. As many as five isotopes were detected internally in one individual. The maximum body burden fraction in a single organ was 0.123 for the thyroid. However, the residence time appeared to be three days or less for all internal depositions. 
TA B LE OF CONTENTS

$\begin{array}{lr}\text { ABSTRACT } & \text { i } \\ \text { INTRODUCTION } & 1 \\ \text { GENERAL } & 2\end{array}$

AREA MONITORING SURVEILLANCE 3

Exclusion Areas 3

Direct Radiation Measurements During Reactor Operations 3

Air Samples 4

Thermoluminescent Dosimeter Measurements 4

Particle Deposition 5

FACILITY RADIOLOGICAL SUPPORT 9

Test Cell Radiation/Contamination Conditions 9

Test Cell Decontamination 11

RADIATION/CONTAMINATION INFORMATION 12

Personnel Radiation Exposure 12

Personnel Contamination $\quad 12$

Vehicle Contamination $\quad 13$

Whole Body Counts 14

FIGURES

TABLES

APPENDIX 
Pan American World Airways, Inc. provided on-site radiological support to the Los Alamos Scientific Laboratory for the Phoebus IB Reactor Test Series. This Test Series consisted of four Experimental Plans conducted between January 25, 1967, and February 23, 1967.

The pertinent on-site radiological data that were obtained by Pan Am in support of the Test Series and post-test activities are presented herein. More detailed on and off-site radiological measurements of the effluent activity have been reported in, "Summary of Results -- Effluent Monitoring -- Phoebus IB EP-IV."

The submittal of this report completes the reporting requirements of Operations Directive No. 66-2, Phoebus IB. 
General information concerning the Experimental Plans (EPs) of the Phoebus IB reactor test series is summarized below.

PHOEBUS IB REACTOR TEST SERIES

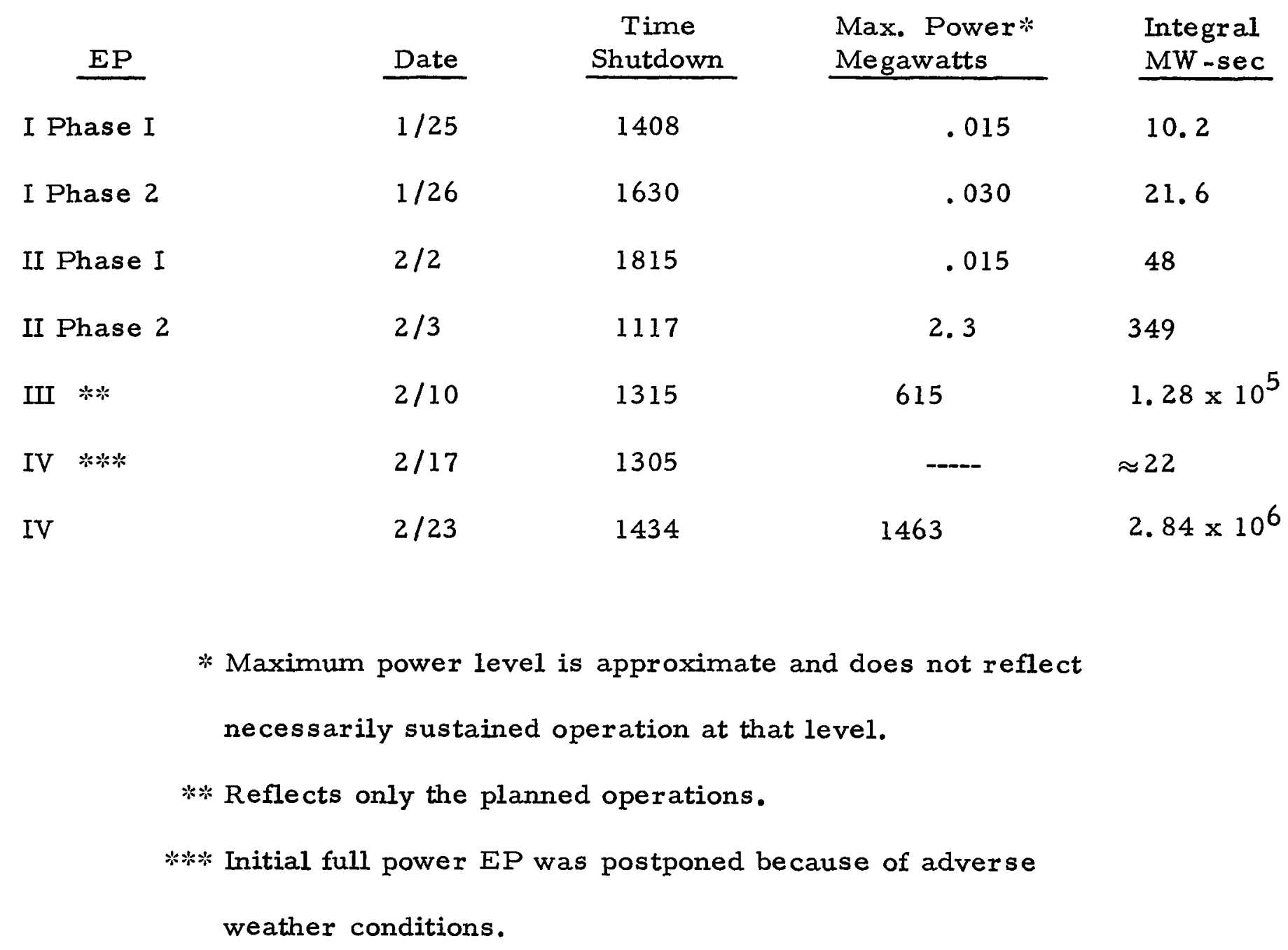


Radiological support for the Phoebus IB reactor test series has been divided for reporting convenience into Area Monitoring Surveillance and Facility Radiological Support.

A. Area Monitoring Surveillance

Area monitoring surveillance was concerned with radiological support conducted outside Test Cell "C" (TCC) during the run and post-run operations.

1. Exclusion Areas

The exclusion area for EPs I and II was as shown in Figure 1 with the nearest populated facility at least 4000 feet away. No additional personnel controls were necessary. For EPs III and IV the exclusion area was as shown in Figure 2.

During the nuclear powered operations of EP-III, occupants of the Reactor Control Point (CP), the Fire Station and the Security Check Point (Main Gate) were directed to seek shelter because they were downwind from the reactor. For EP-IV additional personnel controls outside the exclusion area were unnecessary during the nuclear reactor test.

2. Direct Radiation Measurements During Reactor Operations

The radiation levels at populated facilities during EPs I through III were of little consequence. Even during the full power operation of EP-IV the measurements, as a result of the reactor shield, were considerably lower than during previous full power tests at reduced power levels. The radiation reduction was approximately a factor of 12 without correcting for the difference in power levels. If this correction is applied, the efficacy of the reactor shield appears to be a factor of 16 at a nominal distance of 2 miles. Representative gamma dose rates as measured with portable survey instruments during Phoebus IB, EP-IV, were:

$1.5 \mathrm{mR} / \mathrm{hr}$ outside the Cafeteria and at the Radiation Services check station; $1.1 \mathrm{mR} / \mathrm{hr}$ outside the Technical Operations, Technical Services, and CP Buildings. See Figure 3 for the $\mathrm{CP}$ area survey results. The neutron dose rates were insignificant. 
In addition to the portable instrument surveys, a 15 -station remote area monitoring system (Figure 4) was used outside the Test Cell area to record radiation levels at stationary locations. Table I shows the radiation dose rates at various power levels and the corresponding locations. Figures 5-9 show the radiation decays for the five stations that indicated significant radiation levels following EP-IV. The curves reflect the additive contributions of the reactor decay and Cell activation radiation levels in varying degrees.

3. Air Samples

Air samples, utilizing millipore and charcoal cartridge filters, were taken during each EP. The air sample results until EP-IV were of little significance and did not exceed 0.1 per cent of the guide for fresh fission product activity. After EP-IV the samples were replaced periodically for several days in order to determine the radioactivity associated with cool-down operations and with drainage winds. All sampling locations from 270 degrees counter-clockwise to the $R-M A D$ gave positive indications of airborne radioactivity during some point of the post-test period. Analyses of other samples normalized to "sample off" time indicated activities up to about three times the guide for radiation workers exposed to airborne mixed fission products for 40 hours each week without respiratory protection. Although the maximum activity detected was on the sample collected at the R-MAD Building, extenuating circumstances prevented analysis of the sample. Other samples of significance -- greater than 10 per cent of the guide for the time interval under consideration -- were collected at all the facilities between azimuths of 190 degrees to 116 degrees. Filter samples and charcoal cartridges were not counted immediately after time off and no factors were applied for leaching of the activity from the collection media.

Autoradiography of filter samples was not performed to identify the extent of discrete particle collection on the samples which would distort airborne activity concentration calculations. See Table II for a tabulation of air sample results and locations.

4. Thermolumines cent Dosimeter Measurements

Thermoluminescent dosimeters were employed for EPs I through III at five-degree intervals on the nominal 2.5 mile arc, but no significant doses (greater than $0.4 \mathrm{mR}$ ) were measured. For EP-IV, TLDs were utilized on the 
2.5 mile arc between 043 and 185 degrees -- to straddle the predicted effluent hot line. However, the effluent hot line shifted to 005 degrees; and the TLDs were unaffected by cloud passage or direct reactor radiations.

5. Particle Deposition

Portable survey instruments and vehicles with bumpermounted probes were used after each run to ensure that the NRDS roads and access routes were free from particulate activity. Subsequent surveys were performed along accessible downwind arcs to determine deposited particle concentrations and to collect particles for further analyses.

Except for one particle after EP-III, no other particles were found until after EP-IV. The one particle released during EP-III was located along Road "G", 0.75 miles from the CP intersection, about 30 minutes after shutdown. The portable survey instrument readings on the particle in the field were $6 \mathrm{R} / \mathrm{hr}$, beta gamma, and $3 \mathrm{R} / \mathrm{hr}$, gamma, at one inch. Further examination indicated the particle to have a 128 micron diameter; to decay according to a $t^{-1.04}$ equation; and to exhibit a typical fresh fission product spectrum with a beta activity of $3.84 \times 10^{8}$ disintegrations per minute calculated for 30 minutes after shutdown.

The effluent cloud at the NRDS Main Gate, about three miles from TCC, produced ground level dose rates up to $0.2 \mathrm{mR} / \mathrm{hr}$. Cloud passage started nine minutes after shutdown and ended six minutes later with the peak measurement occurring at the midtime of passage according to portable survey instrument indications.

For EP-IV the first indication of fallout or cloud passage occurred simultaneously with shutdown, 1434 PST, at 12,300 feet and 015 degrees from the reactor. All during the nuclear power operation the remote area monitoring detector at this location registered background. The almost instantaneous increase in reading -- background at 1433 and $200 \mathrm{mR} / \mathrm{hr}$ at 1434 -decayed to $190 \mathrm{mR} / \mathrm{hr}$, then increased to $220 \mathrm{mR} / \mathrm{hr}$. The subsequent decay (See Figure 10.) was attributable to fallout and not cloud passage per se. The measured values undoubtedly reflect variations of particle proximity to the detector, three feet above grade, induced by wind conditions. 
On run night a survey on the 2.5 mile arc using a vehicle with bumper-mounted probes indicated particulate activity between 350 degrees and 17 degrees with the highest activity between 360 and 13 degrees. Particle concentrations were not determined.

On $R+13$ a bumper probe survey was conducted on accessible roads north of the Cell. This survey confirmed the lateral azimuths of radioactive particulate deposition as determined on run night. Extensive concentration measure ments were not made, but the maximum concentration appeared to be at a distance of 5.5 air miles north of the Cell on the Topopah Springs Road.

Because of the extensive site contamination and the delay in its appearance at occupied facilities; and because of the magnitude of effort involved, a chronological sequence of the contamination developments is presented below. Unless stated otherwise, instrument readings are at one inch and have not been corrected for source size, geometry factors, etc.

Date Time

$2 / 23 \quad 1430-$

1800 No contamination detected at occupied NRDS facilities.

1730450 feet south of TCC -- no contamination.

1800800 feet east of TCC -- survey vehicle contaminated inside and out with particles indicating up to $3.5 \mathrm{R} / \mathrm{hr}$, beta-gamma $(\beta \gamma)$

$1800 \quad \mathrm{R}-\mathrm{MAD}-\mathrm{4-5}$ particles per $100 \mathrm{ft}^{2}, 260 \mathrm{\beta \gamma} / 100 \mathrm{\gamma}$

1815 CP -- fallout first detected.

1930 CP Cafeteria -- survey indicated $50 \mathrm{mR} / \mathrm{hr}, \beta \gamma$, on shoe soles of occupants and $5 \mathrm{mR} / \mathrm{hr}, \beta \gamma$, on floor.

$2000-$

2100 Established monitoring road blocks at Main Gate, ETS-1, and at Lathrop Wells Gate.

2000

2200

Extent of road contamination: " $\mathrm{H}^{\prime \prime}$ road between $207^{\circ}$ and $224^{\circ}$, 3-10 mR/hr BY; Second Street, $10 \mathrm{mR} / \mathrm{hr} \beta \gamma$; Lathrop Wells Road from $A \& E$ to two miles west of $A \& E$ Building, 1 particle $/ 100 \mathrm{ft}^{2}$, $20 \mathrm{mR} / \mathrm{hr} \beta \gamma, 2 \mathrm{mR} / \mathrm{hr} \gamma$; access highway one mile south of Main Gate, 1 particle $/ 500 \mathrm{ft}^{2}$ and none at 1.5 miles. 
ETS -1 and E-MAD -- no contamination.

$2100 \quad$ A\&E Parking Lot -- 1 particle $/ 150 \mathrm{ft}^{2}, 35 \mathrm{mR} / \mathrm{hr} \beta \gamma, 5 \mathrm{mR} / \mathrm{hr} \gamma$; 0.7 miles east of $\mathrm{A} \& \mathrm{E}$ Building -- 2 particles $/ 100 \mathrm{ft}^{2}, 12 \mathrm{mR} / \mathrm{hr} \beta \gamma$, $0.5 \mathrm{mR} / \mathrm{hr} \gamma ; 1.4$ miles east of $\mathrm{A} \& \mathrm{E}$ Building - no contamination.

CP Cafeteria -- Smears on tables and floors, $3 \mathrm{mR} / \mathrm{hr} \beta \gamma$, $0.3 \mathrm{mR} / \mathrm{hr} Y$.

$0200 \quad$ ETS-1 -- Discontinued monitoring station.

0300 A\&E Parking Lot -- 30 particles $/ 100 \mathrm{ft}^{3}, 200 \mathrm{mR} / \mathrm{hr} \beta Y, 130 \mathrm{mR} / \mathrm{hr} \gamma$.

0325 CP to R-MAD Road -- 30 particles $/ 100 \mathrm{ft}^{2} ; 150 \mathrm{mR} / \mathrm{hr} \beta Y ; \mathrm{R}-\mathrm{MAD}$ Compound -- 120 particles $/ 100 \mathrm{ft}^{2} ; 50 \mathrm{mR} / \mathrm{hr} \beta \gamma$ and $0.5 \mathrm{mR} / \mathrm{hr} \beta \gamma$ at 3 feet. Cane Springs Road eastward from the Main Gate -60 particles $/ 100 \mathrm{ft}^{2}$ in first half-mile; $150 \mathrm{mR} / \mathrm{hr} \beta \gamma, 1.5 \mathrm{mR} / \mathrm{hr} \gamma$; at 1.6 miles - 20 particles $/ 100 \mathrm{ft}^{2} ; 0.3$ particles $/ 100 \mathrm{ft}^{2}$ from 1.7 miles to 2.3 miles from intersection.

0330 "H" Road westward to Second Street -- 6 particles $/ 100 \mathrm{ft}^{2}$; $200 \mathrm{mR} / \mathrm{hr} \beta \gamma, 10 \mathrm{mR} / \mathrm{hr} \gamma$, maximum.

0330 CP Cafeteria -- Decontaminated. Booties required for entry.

0430 CP Area -- 6 particles detected on booties; $50 \mathrm{mR} / \mathrm{hr} \beta \mathrm{Y}, 2 \mathrm{mR} / \mathrm{hr} \gamma$, maximum.

0630 Outside Weather Bureau Observation Facility -- 2 particles $/ 100 \mathrm{ft}^{2}$; $5 \mathrm{mR} / \mathrm{hr} \beta Y$, and bootie smear indicated $4 \mathrm{mR} / \mathrm{hr} \beta \gamma$.

PAA Carpenter Shop, Inside -- $3 \mathrm{mR} / \mathrm{hr} \beta \gamma$ on smear.

0700 A\&E South Parking Lot was washed effectively.

Brock House in Bus Parking Lot -- 6 particles/100 $\mathrm{ft}^{2}$ on and around house, $150 \mathrm{mR} / \mathrm{hr} \beta \gamma, 1 \mathrm{mR} / \mathrm{hr} \gamma$. Particles removed from shack surface. No contamination detected inside.

ETS-1 -- No contamination in tunnel or inside tunnel entrances.

0715 Main Gate -- Discontinued surveys of all personnel and vehicles leaving the site.

0745 Road from CP to Main Gate after flushing -- 2 spots detected with maximum level of $50 \mathrm{mR} / \mathrm{hr} \beta \gamma$. 
Date $\underline{\text { Time }}$

$2 / 24 \quad 0745$

0800

Road from Main Gate to A\&E -- 3 spots detected with maximum level of $35 \mathrm{mR} / \mathrm{hr} \beta \gamma$.

All areas except $R-M A D$ opened for normal traffic. $R-M A D$ was under control with a contamination release guide of $5 \mathrm{mR} / \mathrm{hr} \gamma$. Release guide at other facilities was $5 \mathrm{mR} / \mathrm{hr} \beta \gamma$.

0900 1130

Survey of air conditioning filters

Rad-Safe Supply Trailer -- $30 \mathrm{mR} / \mathrm{hr} \beta \gamma, 3 \mathrm{mR} / \mathrm{hr} \gamma$.

$\mathrm{CP}$ Buildings, A\&E Building, and Cafeteria $--<3 \mathrm{mR} / \mathrm{hr} \beta \gamma$, $0.3 \mathrm{mR} / \mathrm{hr} Y$.

E. MAD -- $6 \mathrm{mR} / \mathrm{hr} \beta \gamma, 0.5 \mathrm{mR} / \mathrm{hr} \gamma-3$ particles detected.

Road survey after flushing:

Test Cell "A" -- R-MAD Road, 2 particles on road; $7 \mathrm{mR} / \mathrm{hr} \beta \gamma$. Technical Operations Building, north end of parking lot -- $12-15$ particles/100 $\mathrm{ft}^{2} ; 35 \mathrm{mR} / \mathrm{hr} \beta \gamma$.

"H" Road -- 6-8 particles/100 $\mathrm{ft}^{2}$ between $185^{\circ}$ and $205^{\circ}$ and

Second Street had same concentration between $193^{\circ}$ degrees and $195^{\circ}$. However, considerably more activity was detected alongside the road as a result of flushing and collection thereat. CP to R-MAD Road -- 1 particle found.

Main Gate to $A \& E$ and on roads in Support Area -- No contamination detected.

"F" Road from E-MAD to ETS-1 -- No contamination detected.

Cafeteria Parking Lot -- No contamination.

Cafeteria -- Bootie survey indicated $0.4 \mathrm{mR} / \mathrm{hr}$.

$2 / 27 \quad 0830$

Test Cell "A", ETL, and trailers -- Smearable activity of less than $0.2 \mathrm{mR} / \mathrm{hr} \beta \gamma$. CP Building, Technical Services, Technical Operations, Cafeteria, A\&E, PAA Warehouse, PAA Shops, and Medical Dispensary -- No contamination detected.

1400 Road from Burn Pit to A\&E -- No discnete partićles detected. 1700 "F" and "J" Road Junction -- 3 particles $/ 100 \mathrm{ft}^{2} ; 30 \mathrm{mR} / \mathrm{hr} \beta \gamma$. $2 / 28 \quad 1630$

Road from "F" and "J" Junction to Test Cell "C" - 1.5 particles $/ 100 \mathrm{ft}^{2}$ in first half-milre using bumper probes. 
B. Facility Radiological Support

Facility radiological support was concerned with monitoring activities conducted in Test Cell " $\mathrm{C}$ " for the Phoebus IB test series. Radiation monitoring was provided for the re-entries into the Cell following each test. Additionally, surveys were conducted at specific locations at various times to accumulate decay data for application in future tests. Measurement frequency and scope were contingent on radiation levels. Consequently, after the higher powered runs, the decay data are sporadic. However, there is some indication of the affects of the reactor's presence in the Cell, the reactor shield and the shield water. The results of Cell surveys for EPs III and IV appear in Tables III and IV. The results of the Test Cell pad surveys appear in Tables V thru VII. These data do provide a basis for approximating decay rates and radiation intensities at specific locations in the Cell, but only if short-lived activation products are no longer present.

1. Test Cell Radiation/Contamination Conditions

Except for one incident following EP-III, radiation monitoring support activities were of a routine nature until EP-IV.

After EP-III a radiation monitor was leaving the Cell, and his attention was drawn to a sudden radiation increase without an obvious cause. Further inspection revealed the presence of a wire on the ground -- 600 feet from the reactor and about 30 feet east of the 200-foot water tower. Without source size correction, the radiation level was about $100 \mathrm{R} / \mathrm{hr}$ at six inches from the wire. It was retrieved, emplaced in a storage pig, and taken to the R-MAD Building for identification. The wire was identified as a copper-constantan and tungstenrhenium thermocouple. Radiation decay data are plotted in Figure 11. Two effective half-lives of about three hours and 20 hours can be determined from the curve. A spectral analysis was not performed to further identify the radioisotopes present in the wire.

After EP-IV an initial survey team, proceeding from the south, went 200 feet inside the Main Gate of Test Cell "C" for a quick survey three hours after shutdown. Smears taken at distances ranging from 1900 to 450 feet from the reactor indicated contamination levels less than $0.2 \mathrm{mR} / \mathrm{hr}$, open window.

The other initial survey team, approaching the Cell 
from the east -- the downwind direction at that time -detected particulate contamination simultaneously with

a cooling pulse about three hours after shutdown. The uncorrected radiation levels were up to $3500 \mathrm{mR} / \mathrm{hr}$, open window, at one inch from the particles, both inside and outside of the vehicle. Subsequent entries were not comducted until the next day, $R+1$.

In anticipation of gross contamination in the Cell, all entrants were clothed in double anti-contamination (Anti-Cs) clothing and with respiratory protection. The Rods team entered the Cell about 19 hours after shutdown. Dose rates ranging up to $40 \mathrm{R} / \mathrm{hr}$ prohibited extensive Cell surveys. The contamination levels (all measurements at one inch) on the rubber boots of Rods team members upon leaving the Cell were as high as $2000 \mathrm{mR} / \mathrm{hr}$, gamma.

The gross contamination throughout the Cell resulted from pulse cooling, which continued for about two minutes each time at ever increasing intervals. The shed was positioned over the reactor about 26 hours after shutdown to minimize the subsequent particle distribution resulting from pulse cooling. The cooling operation continued for 72 hours after shutdown.

Entries were kept to a minimum for the next few days. Consequently, surveys were not conducted and data are lacking. Four days after the run, radiation measurements at one inch from particles outside the double doors of the Pump Room indicated $20 \mathrm{R} / \mathrm{hr}$, beta-gamma, and $6 \mathrm{R} / \mathrm{hr}$, gamma. Smears from 33 various locations on the fifth day had radiation levels up to $20 \mathrm{R} / \mathrm{hr}$, beta-gamma, and $5 \mathrm{R} / \mathrm{hr}$, gamma, with an average beta-gamma to gamma ratio of 6.5 . The contamination levels on booties worn on the reactor pad were as high as $12 \mathrm{R} / \mathrm{hr}$, beta-gamma, and $2 \mathrm{R} / \mathrm{hr}$, gamma. Other representative contamination levels were:

Location

Test Cells' Main Gate Outside, Air Intake Building Top of FCR Stairs Top of Basement Stairs
Contamination Levels

Beta-gamma Gamma

$360 \mathrm{mR} / \mathrm{hr}$

$60 \mathrm{mR} / \mathrm{hr}$ $10,000 \mathrm{mR} / \mathrm{hr}$ $1,800 \mathrm{mR} / \mathrm{hr}$ $200 \mathrm{mR} / \mathrm{hr}$ $600 \mathrm{mR} / \mathrm{hr}$ $740 \mathrm{mR} / \mathrm{hr}$ 
The radiation levels encountered during re-entries appear in Tables III - VII and in the selected survey results. (See Appendix.) Survey results at specific locations did show some variation because of the accumulation and transportation of particulate activity throughout the Cell. As an example, in Table VII the dose rate of $12 \mathrm{R} / \mathrm{hr}$, three feet above ground, was measured 300 hours after shutdown. This was attributable to an accumulation of radioparticulate activity at the edge of the reactor pad resulting from decontamination efforts.

2. Test Cell Decontamination

Decontamination (decon) efforts in the Cell commenced March 1, the day after the reactor was returned to the R-MAD Building, and consisted of several methods -- none of which was universally superior to any other method.

In general, decon started on the higher structures and surfaces, subsequently working downward to ground level. The methods that were used included: vacuuming; flushing with copious amounts of water; applying foam to suspend particulates, then flushing with water; using neutral detergents, using bases with a pH of 10-11; using acids with a $\mathrm{pH}$ of about 3; the use of sweeping compound; swabbing with alcohol; removing and replacing dirt; and painting.

Airborne activities in the Cell fluctuated depending on the wind and type of decon effort in progress. To eliminate the possibility of even one particle being inhaled double Anti-Cs and respiratory protection were required for most of the first month's decon activities.

Many of the decon efforts had to be repeated in the same areas as often as five times because of the cross-contamination created by the wind blowing from contaminated into decontaminated areas.

As might be expected, the decon of all painted surfaces proved to be accomplished more easily than the decon of comparable non-painted surfaces. Based on this decon experience, it was estimated that the plain surfaces took ten times as long as the painted surfaces.

The total decon operation involved large quantities of materials. About 500, 000 gallons of water, 130 gallons of foam solution, 50 gallons of base, 110 gallons of acid, 165 gallons of alcohol, and 800 gallons of paint were used; 
approximately 500 cubic yards of trash and vacuumed materials were collected and disposed of by burial; and 750 cubic yards of dirt/sand were removed and replaced.

The total cost of the decon operations was $\$ 98,100$, which included the cost of materials, heavy equipment operations, 5, 050 manhours actually spent on decon and 500 monitoring manhours in support of the decon efforts.

\section{Radiation/Contamination Information}

\section{Personnel Radiation Exposures}

Cumulative radiation exposures for all personnel involved with the Phoebus IB reactor test series totaled 112.5 roentgens (R) for the period 1-23-67 through 3-31-67. Of this total, an estimated $80 \mathrm{R}$ were attributable to decontamination efforts at the Cell; and $14 \mathrm{R}$ were assigned to the monitoring force. A weekly breakdown of exposures is shown in Table VIII. The maximum exposure for a monitor was $1.17 \mathrm{R}$ and for non-monitoring personnel, 2. $02 \mathrm{R}$.

\section{Personnel Contamination}

Personnel contamination incidents prior to EP-IV were of little consequence. For the period of four weeks following EP-IV, activity was detected on 216 personnel out of the 4, 100 checks performed. Of these numbers, 176 were clothing contaminations with levels up to $200 \mathrm{mR} / \mathrm{hr}$, beta gamma, uncorrected. There were $40 \mathrm{skin}$ contamination incidents with activities up to $150 \mathrm{mR} / \mathrm{hr}$, beta-gamma, uncorrected. Incidents involving both clothing and skin contamination have been recorded only as skin contamination cases.

Fifty of the incidents occurred on run night and the next day and involved personnel outside the exclusion area. Of these, 20 involved skin contamination. All skin contamination cases were decontaminated to acceptable levels. In most cases, clothing was decontaminated successfully. However, in several instances, clothing was retained until the activity decayed sufficiently for release.

The extent of the contamination on-site was of sufficient magnitude that the release guides on run night were increased to $25 \mathrm{mR} / \mathrm{hr}$, open window. On the next day the site 
release guides were $5 \mathrm{mR} / \mathrm{hr}$, beta-gamma, except at the $\mathrm{R} \cdot \mathrm{MAD}$ where the level was $5 \mathrm{mR} / \mathrm{hr}$, gamma. Thereafter, the release levels were reduced to the normal release guides.

Even though detectable activities were within the higher release guides, personnel decontamination was attempted to reduce the activity levels when practical.

A discrete particle was detected on each of two skin contamination cases. The particles were retained for analysis and measurement purposes.

One particle, with an approximate diameter of 70 microns had an indicated beta activity of 3.76 microcuries at the earliest estimated time of deposition on the individual. The particle was detected on the left cheek, a radial distance of one, $+1 / 4$, inch from the eye. Utilizing this information and the residence time, the localized dose was calculated to be 30.4 rads to the volume of tissue having a surface area of one square centimeter surrounding the particle. The assigned dose to the lens of the eye was calculated to be $415+207$ mrads, based on the uncertainty of distance from the eye.

The second particle with a diameter of about 120 microns had an indicated activity of 12.3 microcuries at the time of deposition on the individual's right forearm. With this information and the residence time, the localized dose was calculated to be 4.9 rads to the volume of tissue having a surface area of one square centimeter surrounding the particle.

3. Vehicle Contamination

The contamination release guides for vehicles were the same as for personnel release guides.

On run night and the next day 37 vehicles -- none of which had been in the exclusion area -- had detectable contamination levels up to $200 \mathrm{mR} / \mathrm{hr}$, beta-gamma, uncorrected. Of these 37 vehicles, 17 were privately owned. Decontamination to within guides was successful in each case.

Contaminated vehicles used in the exclusion area were restricted to that area in order to keep from contaminating additional vehicles. For the 37-day period ending March 31, 1967, a total of 86 vehicles, out of the 2, 600 vehicle contami- 
nation checks that were performed, were contaminated. All were successfully deconned.

\section{Whole Body Counts}

Whole body counts were performed on 61 employees in the period following the test series and decontamination efforts in TCC. The employees selected were from five different organizations and were those most likely to have internally deposited radioisotopes arising from airborne radiocontamination.

On run night GM probe surveys of $2 \mathrm{mR} / \mathrm{hr}$, beta-gamma, indicated thyroid radioactivity uptakes on two employees. Whole body counts on each employee confirmed the presence of only one radioisotope, iodine -133 . The quantity of iodine -133 was calculated to be 0.036 microcuries in each of the two individuals at the estimated time of uptake. These data have been included in the statistics below.

Positive activities of non-natural occurring radioisotopes were detected in 19 individuals. The radioisotopes detected were iodines -131 and 133; tellurium-iodine-132; ruthenium-103 and -106; zirconium-niobium-95; and bariumlanthanum - 140 .

Three individuals had uptakes of only one isotope; eight, two isotopes; four, three isotopes; three, four isotopes; and one individual had five isotopes detected internally.

The sum of the fractions of body burdens for the is otopes involved in no case exceeded 0.125 for a critical organ. The use of the critical organ for estimating body burden fractions was conservative based on recount results. Recount data appeared to indicate the activity residence time was three days or less regardless of the isotope(s) or individual involved. The short residence time indicated transient gastrointestinal tract exposures. However, critical organs other than the GI tract were used for calculating body burden fractions.

The maximum body burden fraction calculated for the thyroid was 0.123; for the kidney, 0.049; for bone, 0.01; and for the total body was 0.01 . 
$F$ I G U R E S 


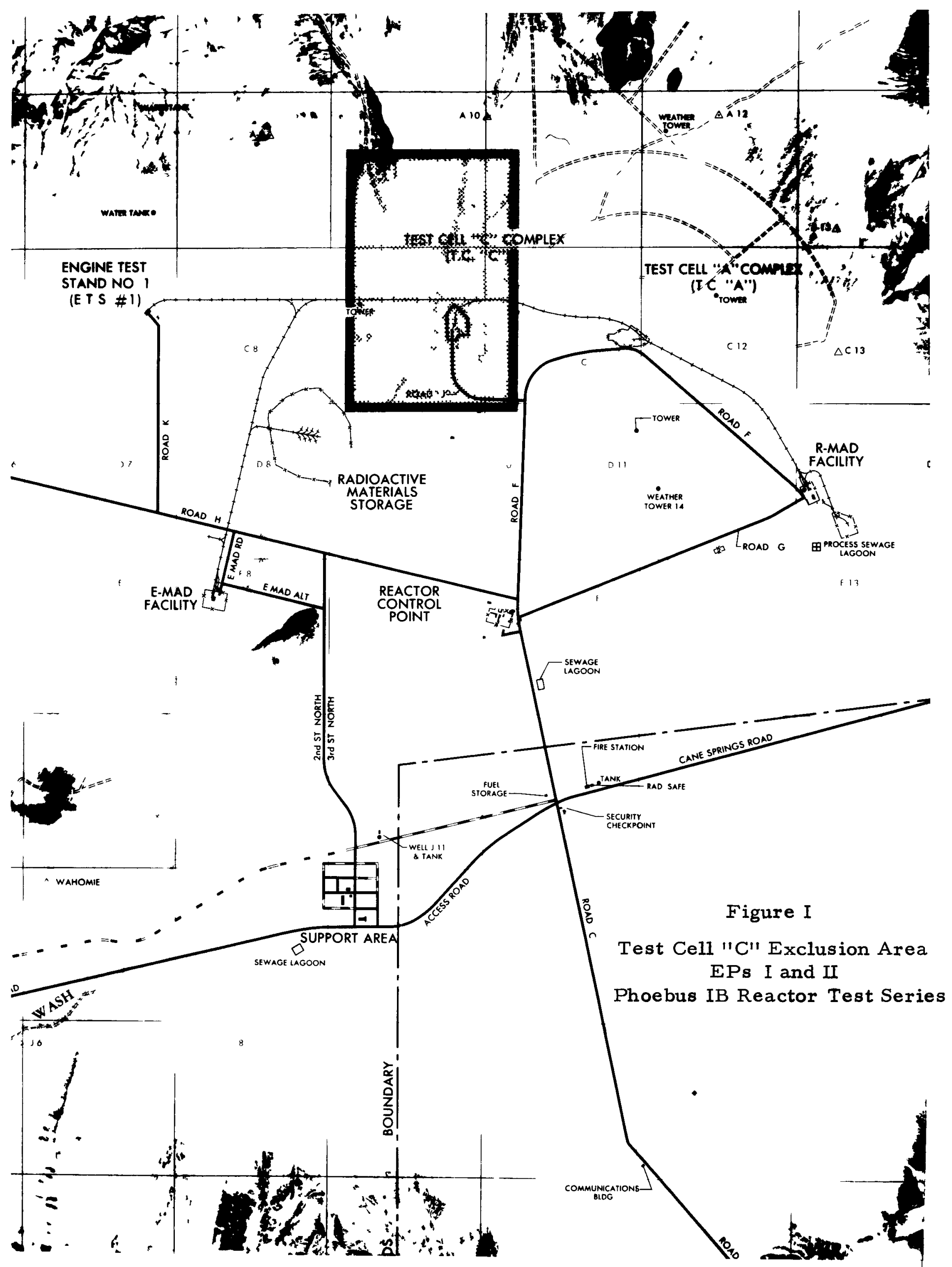




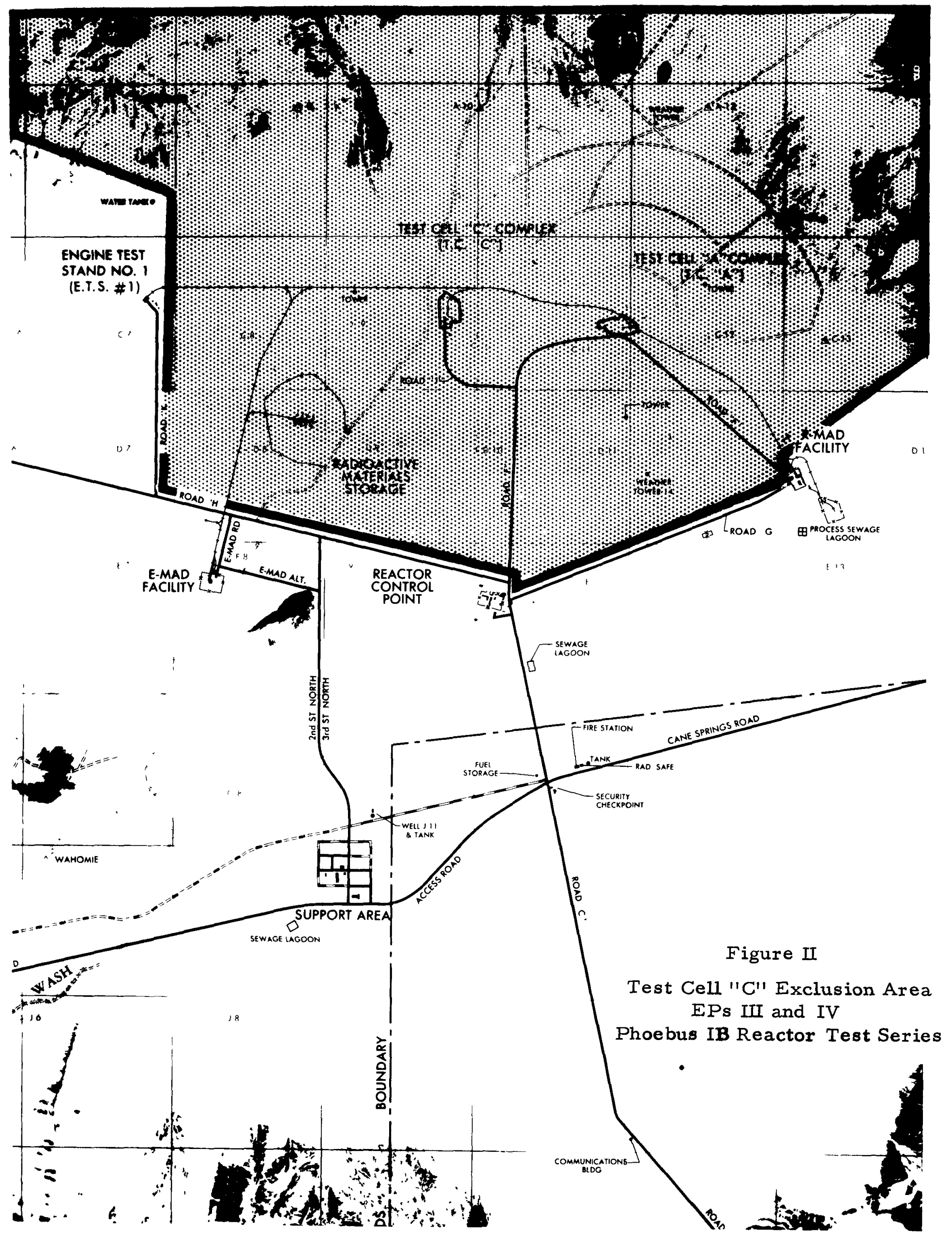


FULL POWER RUN OF PHOEBUS IB EP-IV

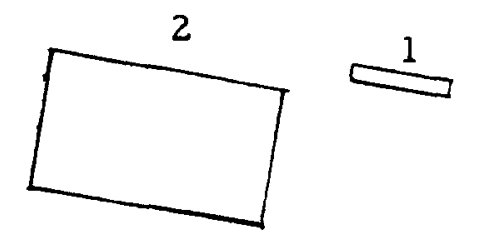

1. Cashier Trailer

2. Main Cafeteria

3. Tech. Ops. Building

4. Tech. Services Building

5. C. P. Building

6. Power House

7. LASL Warehouse

8. Building 3104

9. NRDS Medical Facility

10. Motor Pool Shop
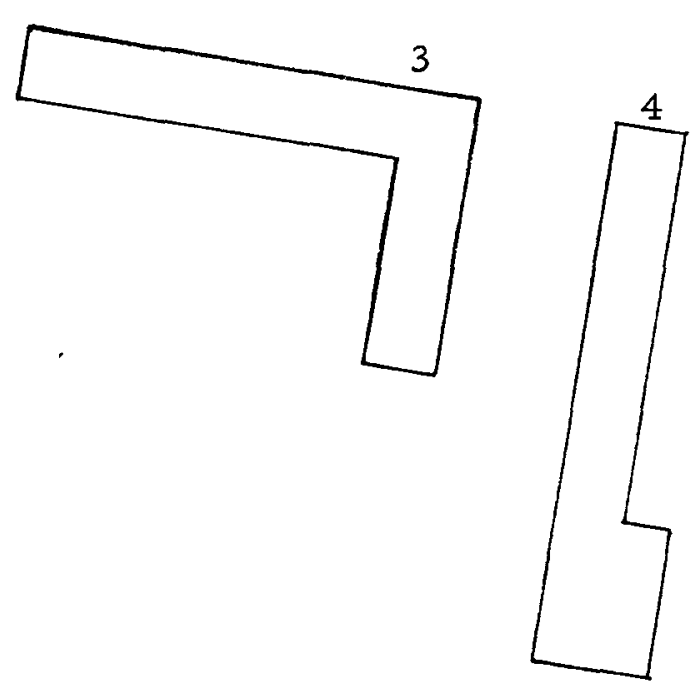

Radiation Level, $\mathrm{mR} / \mathrm{hr}$

\section{Outside}

Inside

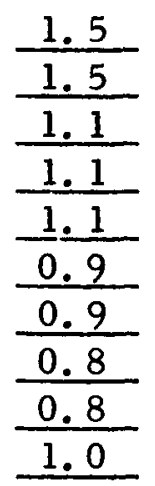

\begin{tabular}{l}
\hline- \\
\hline 1.5 \\
\hline 0.9 \\
\hline 0.9 \\
\hline 0.9 \\
\hline 0.3 \\
\hline 0.8 \\
\hline 0.7 \\
\hline 0.7 \\
\hline 0.9 \\
\hline
\end{tabular}
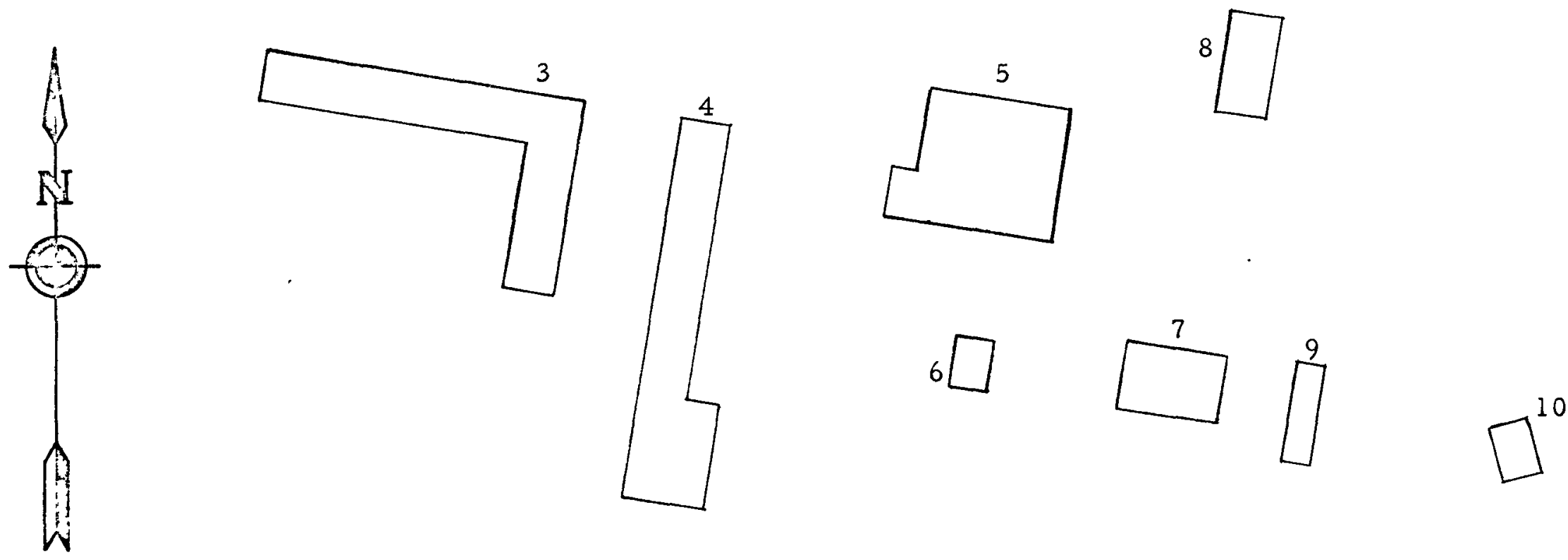


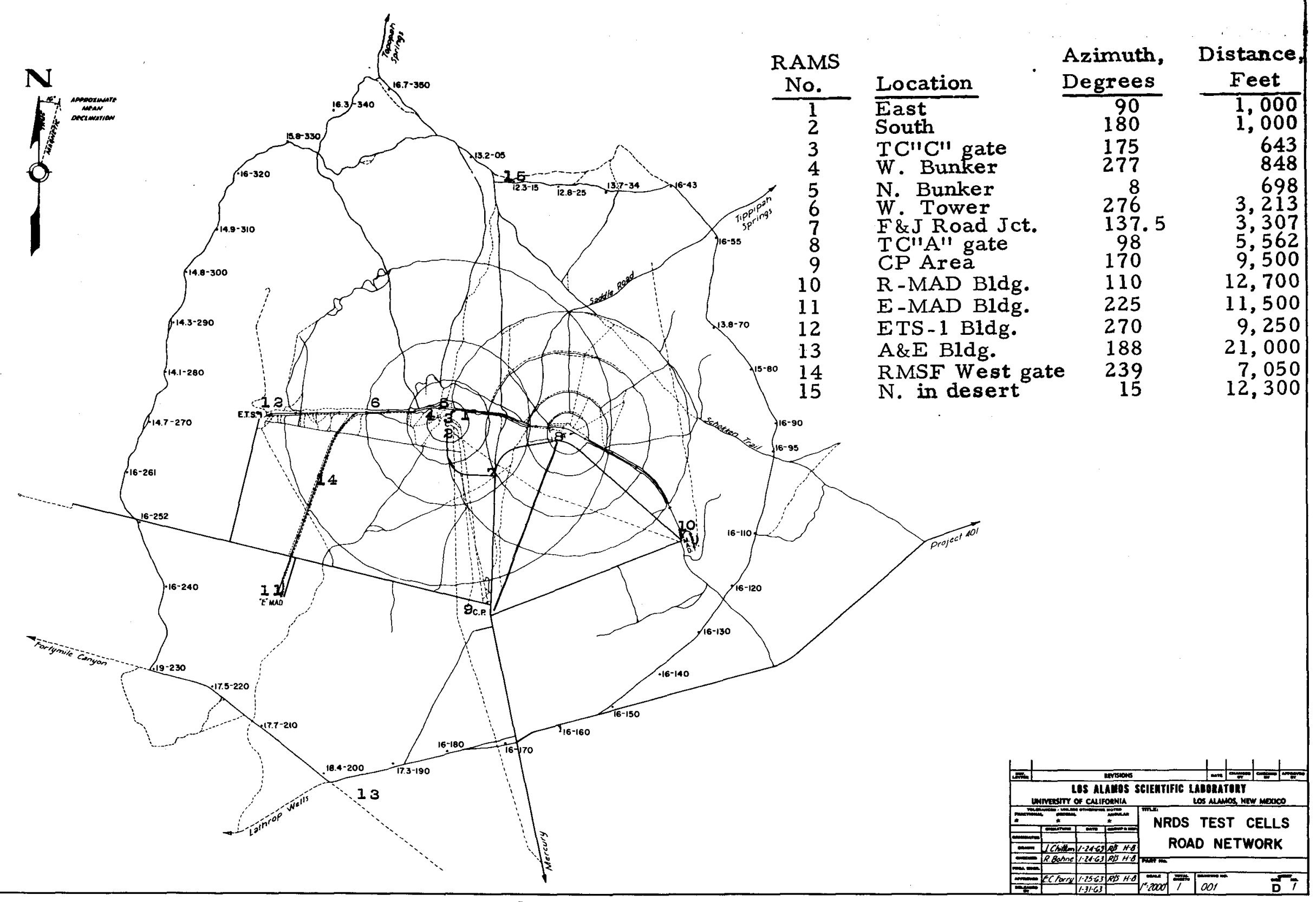

Figure 4

Remote Area Monitoring Detector Locations

Phoebus IB Reactor Test Series 


\section{Figure 5}

\section{POST -PHOEBUS IB, EP-IV Radiation Measurements \\ at \\ Remote Detector \# 1}

-Azimuth 900, Distance 1000 Feet -



Time After Shutdown, Hours 
Figure 7

\title{
POST - PHOEBUS IB, EP-IV \\ Radiation Measurements
}

\author{
at \\ Remote Detector \#3 \\ TC"C" Main Gate
}

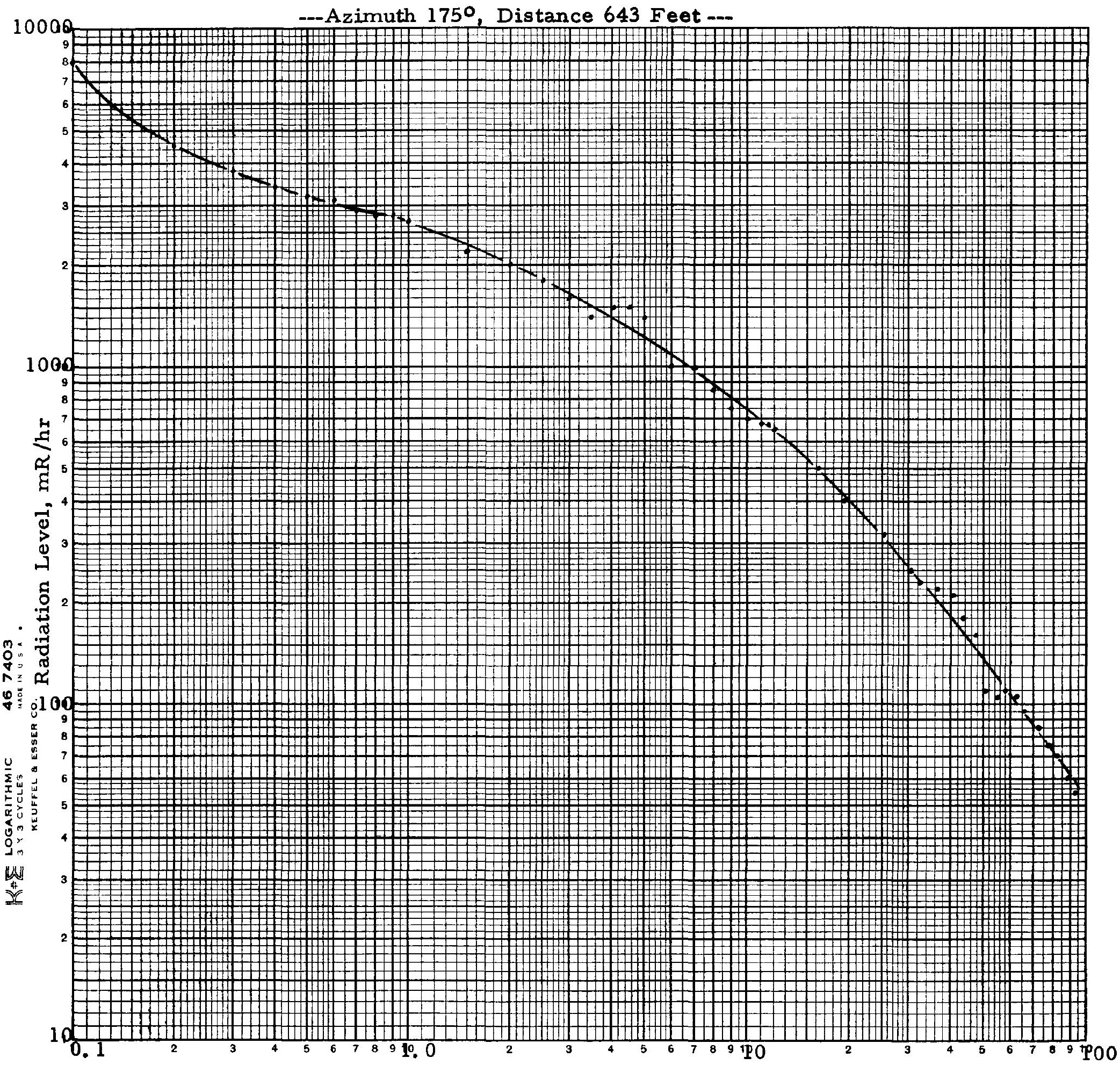

Time After Shutdown, Hours 
Figure 8

POST -PHOE BUS IB, EP-IV

Radiation Measurements

at

Remote Detector \#4

West Bunker

---Azimuth $277^{\circ}$, Distance 848 Feet---



Time After Shutdown, Hours 
Figure 9

POST-PHOEBUS IB, EP-IV

Radiation Measurements

at

Remote Detector \#5

North Bunker

-Azimuth 80, Distance 698 Feet

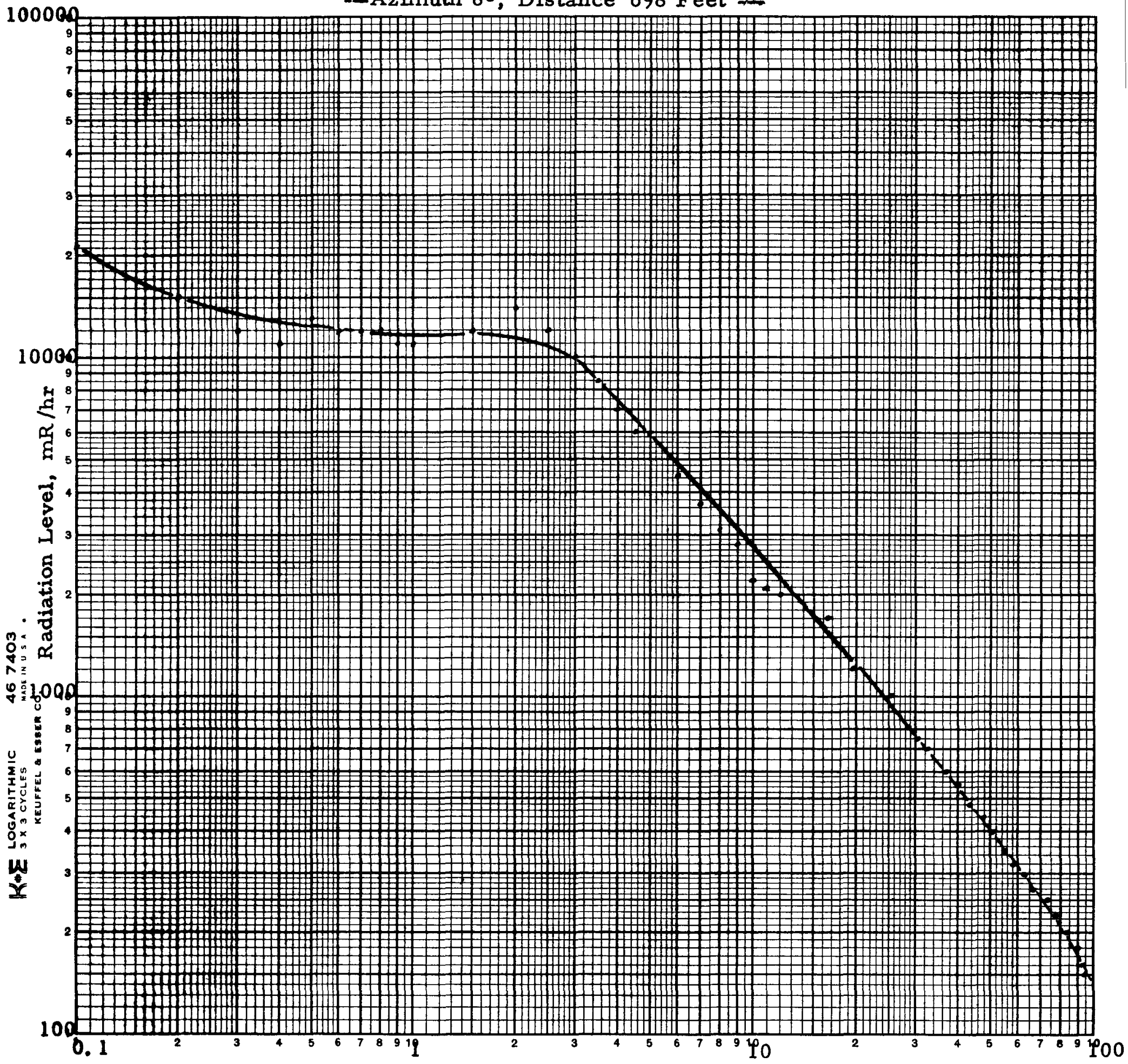

Time After Shutdown, Hours 


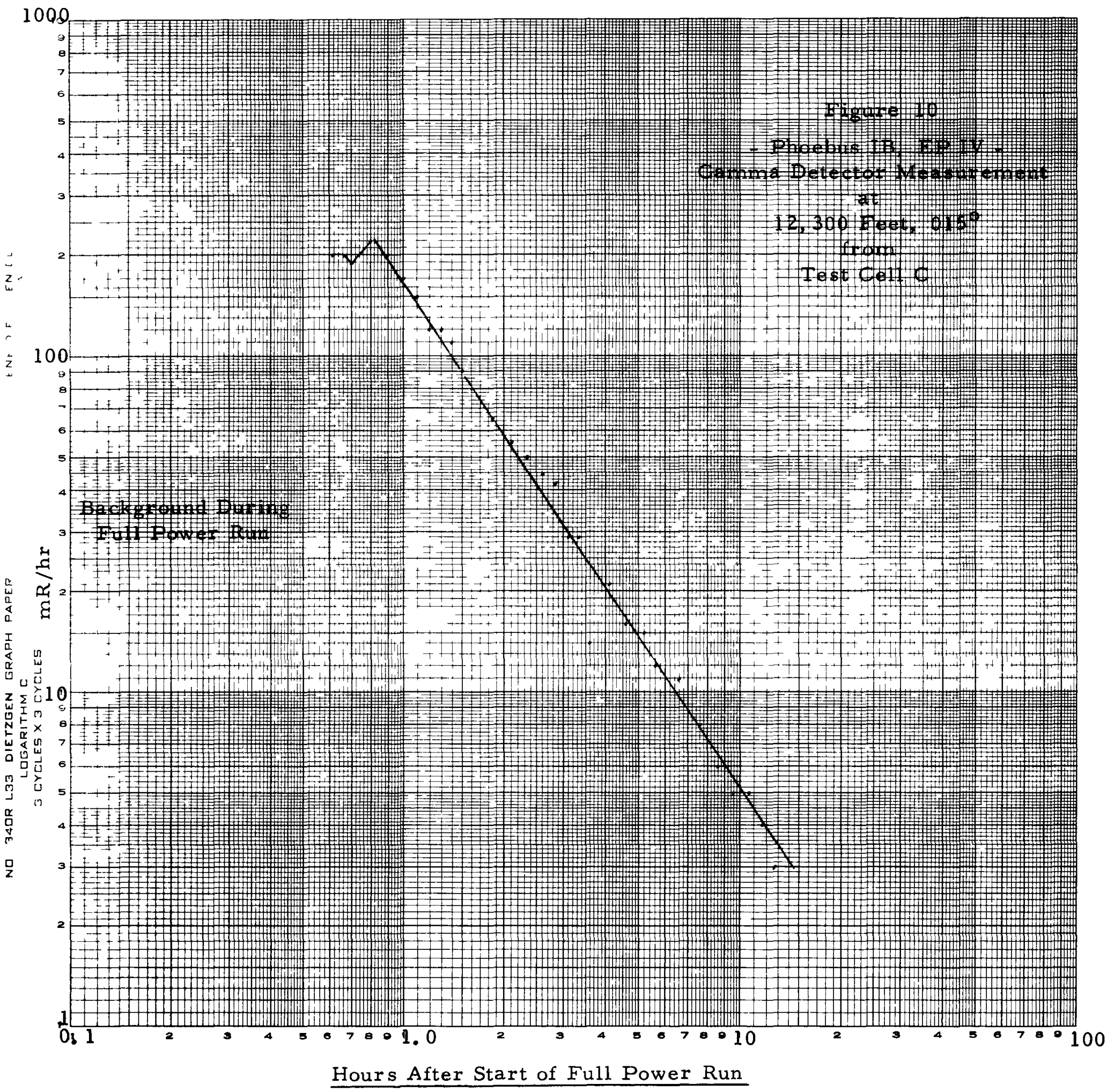




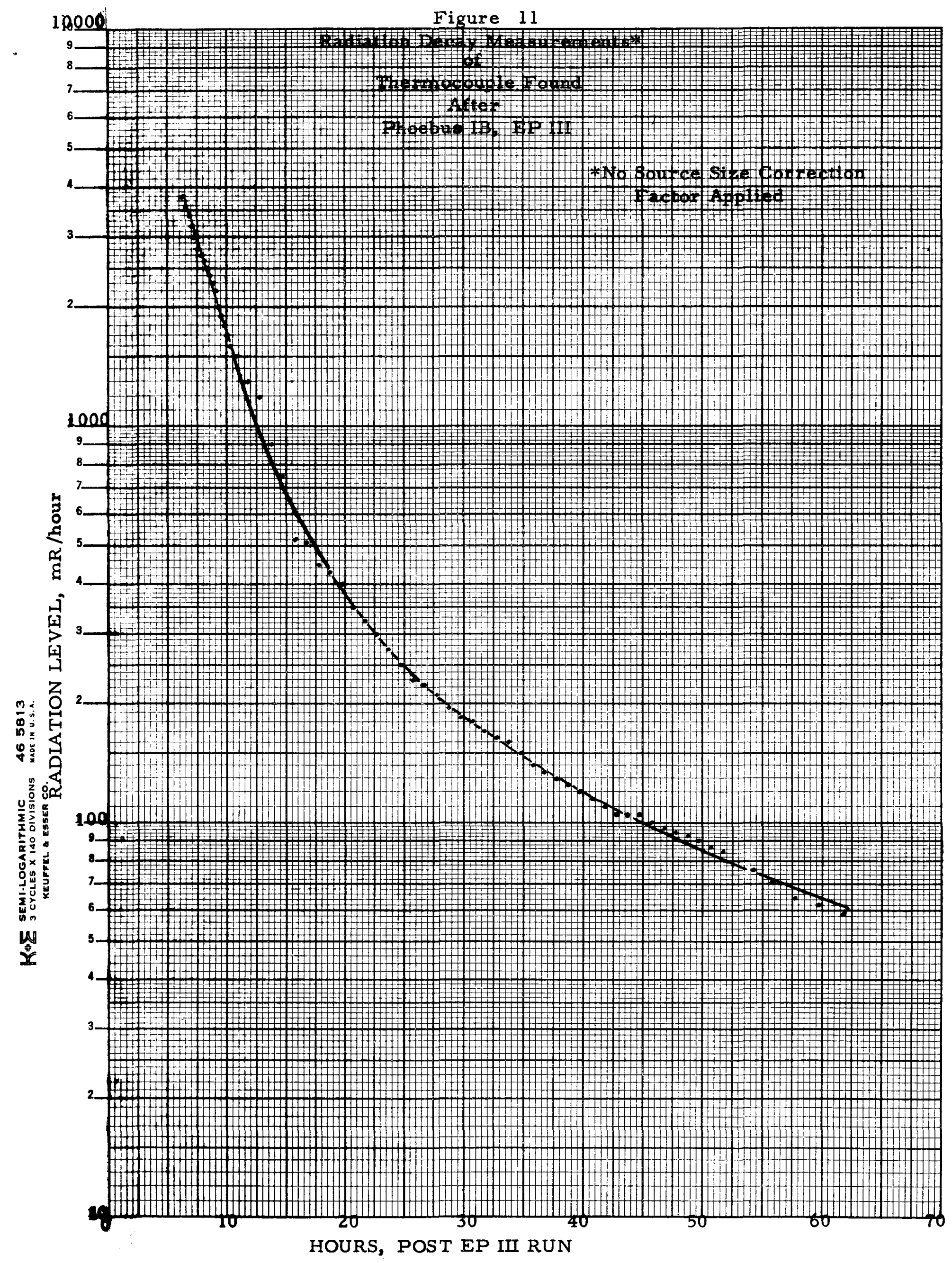


T A B L E S 
RAMS STATION RADIATION MEASUREMENTS* for

PHOEBUS IB REACTOR TEST SERIES

Time After

Power

Level

$10 \mathrm{KW}$

$30 \mathrm{KW}$

$2 \mathrm{MW}$

$500 \mathrm{MW}$

$615 \mathrm{MW}$

$1463 \mathrm{MW}$
Shutdown,

Hrs.

0.1

0.2

0.3

0.4

0.5

0.6

0.7

0.8

0.9

1. 0

1. 5

2. 0

2. 5

3. 0

3. 5

4. 0

4. 5

5.0

6. 0

7. 0

8. 0

9. 0

10. 0

11.0

12. 0

16. 4

19. 4

25.4

30.4

32. 4

\begin{tabular}{lll}
1 & & \multicolumn{1}{c}{2} \\
1.5 & & 0.5 \\
4 & & 3 \\
200 & & 300 \\
$19 \mathrm{R}$ & & $20 \mathrm{R}$ \\
$20 \mathrm{R}$ & & $25 \mathrm{R}$ \\
$40 \mathrm{R}$ & & $35 \mathrm{R}$
\end{tabular}

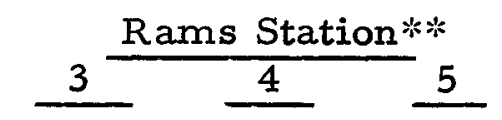

6

64

70

475

250R

500R

600R

420

400

390

350

350

310

290

250

210

180

150

120

120

92

77

67

52

47

40

37

27

20

14

13

12
1500

450

350

310

310

280

\begin{abstract}
8000
\end{abstract}
4500

3800

3400

3200

3100

270

260

250

240

210

180

160

140

130

100

120

120

83

73

73

58

58

48

41

30

24

14

14

11

1800

1600

1400

1500

1500

1400

1000

1000

850

750

700

680

650

500

400

320

250

230

$\begin{array}{llll}2900 & 900 & 12000 & 28 \\ 2800 & 850 & 12000 & 28 \\ 2800 & 800 & 11000 & \\ 2700 & 750 & 11000 & \\ 2200 & 750 & 12000 & \\ 2000 & 650 & 14000 & \end{array}$

$2000 \quad 21000 \quad 32$

1200

1200

1100

1000

950

650
600

500

450

400

350

310

270

215

190

160

140

120

110

85

60

45

37

33
$12000 \quad 30$

\section{5}

80

5000

$500 \mathrm{R}$

500R

$\mathrm{P}$

$15000 \quad 30$

$11000 \quad 30$

$13000 \quad 30$

$12000 \quad 28$

14000

\section{0}

10000

8500

7000

6000

6000

4500

3700

3100

2800

2200

2100

2000

1700

1200

1000

750

700 
Time After

Power Shutdown,

36. 4
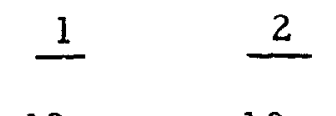

Rams Station **

40.4

43. 4

47.4

50.4

54.9

12

7

7

3

5

4

1
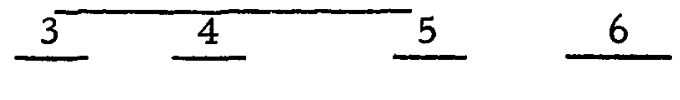

7

57.9

62.9

10

220

600

$210 \quad 25$

550

180

480

160

440

110

400

105

350

66.1

73. 4

77. 4

81.9

3
3
3
2
2
2

3

$110 \quad 11$

320

$105 \quad 10$

300

95

10

270

85

75

250

70

225

200

89. 4

1.5

1. 5

60

180

2

92.4

1. 5

1

113.2

115.9

116.3

2. 5

3

1. 7

160

1.5

1

1

1.2

60

150

105

270

43

340

117.5

117.55

70

25

117.65

6

118.9

119.1

122. 4

1

1

1

142.5

152. 4

1

B

2
1
1
1
1
1

44

110

110

110

105

105

95

$40 \quad 2$

90

$35 \quad 1$

90

NOTE: B represents background

$\mathrm{P}$ represents offscale, greater than $1000 \mathrm{R} / \mathrm{hr}$.

*Results in $\mathrm{mR} / \mathrm{hr}$ unless followed by $\mathrm{R}$ then results are in $\mathrm{R} / \mathrm{hr}$.

$* *$ No. 1 -- 1,000 feet at 90 degrees.

No. 2 -- 1,000 feet at 180 degrees.

No. 3 -- 643 feet at 175 degrees.

No. 4 -- 848 feet at 277 degrees.

No. 5 -- 698 feet at 8 degrees.

No. 6 - 3,213 feet at 276 degrees.

No. $7-3,307$ feet at 135.5 degrees.

No. 8 -- 5,562 feet at 98 degrees. 
Table II

Phoebus IB

On-Site Air Sampling Results

Post EP-IV

ETS-1

E-MAD

$9300^{\prime}$

$223^{\circ}$

Production Control

93001

$19,400^{1}$

A \& E Outside

C****

\begin{tabular}{|c|c|c|c|c|c|c|c|c|c|c|c|c|c|c|c|}
\hline Off & $F^{*}$ & Is otopes $* *$ & $C * * * *$ & Off & $F *$ & Is otopes $* *$ & $\mathrm{C} * * * *$ & Off & $F *$ & Is otopes $*$ k* & $C * * * *$ & Off & $F *$ & Is otope $s * *$ & $C *$ \\
\hline $\begin{array}{l}1630 \\
2 / 23\end{array}$ & 14.8 & --- & N.S. & $\begin{array}{l}1625 \\
2 / 23 \\
\end{array}$ & 14 & $\begin{array}{l}132 \mathrm{Te}-\mathrm{I} \\
133 \mathrm{I}\end{array}$ & $\begin{array}{l}\mathrm{T} \\
\mathrm{T}\end{array}$ & $\begin{array}{l}1620 \\
2 / 23 \\
\end{array}$ & 18 & --- & N.S. & $\begin{array}{l}1615 \\
2 / 23 \\
\end{array}$ & 27 & --- & --- \\
\hline $\begin{array}{l}2400 \\
2 / 23\end{array}$ & 163 & $\begin{array}{l}132 \mathrm{Te}-\mathrm{I} \\
133 \mathrm{I}\end{array}$ & $\begin{array}{l}\mathrm{T} \\
\mathrm{T}\end{array}$ & $\begin{array}{l}2350 \\
2 / 23 \\
\end{array}$ & 173 & $\begin{array}{l}132 \mathrm{Te}-\mathrm{I} \\
133_{\mathrm{I}}\end{array}$ & $\begin{array}{r}5.4 \\
11.2 \\
\end{array}$ & $\begin{array}{l}0520 \\
2 / 24\end{array}$ & 900 & $\begin{array}{l}132 \mathrm{Te}-\mathrm{I} \\
133_{\mathrm{I}}\end{array}$ & $\begin{array}{r}125 \\
73\end{array}$ & $\begin{array}{l}2335 \\
2 / 23\end{array}$ & 8970 & $\begin{array}{l}132_{\mathrm{Te}-\mathrm{I}} \\
133_{\mathrm{I}}\end{array}$ & $\begin{array}{r}15 \\
5.8\end{array}$ \\
\hline $\begin{array}{l}0520 \\
2 / 24 \\
\end{array}$ & 250 & $\begin{array}{l}\text { I3LTe-I } \\
133^{I}\end{array}$ & $\begin{array}{l}\mathrm{T} \\
\mathrm{T}\end{array}$ & $\begin{array}{l}0505 \\
2 / 24 \\
\end{array}$ & 126 & $\begin{array}{l}\text { T32 Te -1 } \\
133_{\mathrm{I}}\end{array}$ & $\begin{array}{l}3.2 \\
6.7 \\
\end{array}$ & $\begin{array}{l}1600 \\
2 / 24 \\
\end{array}$ & 14 & $-\cdots$ & & $\begin{array}{l}0405 \\
2 / 24 \\
\end{array}$ & 1820 & $\begin{array}{l}\mathrm{T} 3 \mathrm{~L}_{\mathrm{Te}-1} \\
133_{\mathrm{I}}\end{array}$ & $\begin{array}{l}7.3 \\
1.6 \\
\end{array}$ \\
\hline $\begin{array}{l}0845 \\
2 / 25 \\
\end{array}$ & 26.4 & -- & N.S. & $\begin{array}{l}1640 \\
2 / 24\end{array}$ & 72 & $\begin{array}{l}132 \mathrm{Te}-\mathrm{I} \\
133_{\mathrm{I}}\end{array}$ & $<1$ & $\begin{array}{l}0830 \\
2 / 25\end{array}$ & 16.6 & $-\cdots$ & & $\begin{array}{l}1700 \\
2 / 24\end{array}$ & 44 & FFP & $\mathrm{T}$ \\
\hline $\begin{array}{l}1630 \\
2 / 25 \\
\end{array}$ & 7 & $\overline{---}$ & N.S. & $\begin{array}{l}0835 \\
2 / 25\end{array}$ & 0.9 & $\begin{array}{l}132 \mathrm{Te}-\mathrm{I} \\
133_{\mathrm{I}}\end{array}$ & $<_{<1}^{1.1}$ & $\begin{array}{l}1645 \\
2 / 25\end{array}$ & 20 & - & & $\begin{array}{l}0825 \\
2 / 25\end{array}$ & 2.5 & FFP & $\mathrm{T}$ \\
\hline $\begin{array}{l}0930 \\
2 / 26 \\
\end{array}$ & 29 & $131 \mathrm{I}$ & $\mathrm{T}$ & $\begin{array}{l}1635 \\
2 / 25 \\
\end{array}$ & 8.8 & $\begin{array}{l}132 \mathrm{Te}-\mathrm{I} \\
133_{\mathrm{I}}\end{array}$ & $\begin{array}{l}\mathrm{T} \\
\mathrm{T}\end{array}$ & $\begin{array}{l}0915 \\
2 / 26 \\
\end{array}$ & 50 & -- & & $\begin{array}{l}1650 \\
2 / 25 \\
\end{array}$ & 21 & -- & $\bar{\cdots}$ \\
\hline $\begin{array}{l}1720 \\
2 / 26 \\
\end{array}$ & 16 & -- & N.S. & $\begin{array}{l}0920 \\
2 / 26 \\
\end{array}$ & 41 & $131_{1}$ & $<1$ & $\begin{array}{l}1705 \\
2 / 26 \\
\end{array}$ & 16.6 & -- & & $\begin{array}{l}0845 \\
2 / 26 \\
\end{array}$ & 82 & $\begin{array}{l}13 I_{I} \\
133_{I}\end{array}$ & $\begin{array}{l}\mathrm{T} \\
\mathrm{T} \\
\end{array}$ \\
\hline $\begin{array}{l}0845 \\
2 / 27 \\
\end{array}$ & 30.8 & $\cdots$ & N.S. & $\begin{array}{l}1710 \\
2 / 26 \\
\end{array}$ & 17 & N.S. & N.S. & $\begin{array}{l}0910 \\
2 / 27 \\
\end{array}$ & 17.2 & $\begin{array}{l}132 \mathrm{Te}-1 \\
133_{\mathrm{I}}\end{array}$ & $\begin{array}{c}\mathrm{T} \\
<0.2 \\
\end{array}$ & $\begin{array}{l}1700 \\
2 / 26\end{array}$ & 32 & $\begin{array}{l}131_{1} \\
133_{1}\end{array}$ & $\begin{array}{l}\mathrm{T} \\
\mathrm{T}\end{array}$ \\
\hline & & & & $\begin{array}{l}0855 \\
2 / 27\end{array}$ & 28.8 & $\begin{array}{l}132 \mathrm{Te}-\mathrm{I} \\
133_{\mathrm{I}}\end{array}$ & $\begin{array}{l}<1 \\
<0.7\end{array}$ & & & & & $\begin{array}{l}0920 \\
2 / 27\end{array}$ & 36 & -- & -- \\
\hline
\end{tabular}

\begin{tabular}{|c|c|c|c|c|c|c|c|c|c|c|c|c|c|c|c|}
\hline Off & $F^{*}$ & Is otopes $* *$ & $C * * * *$ & Off & $F *$ & Is otopes $* *$ & $\mathrm{C} * * * *$ & Off & $F *$ & Is otopes $*$ k* & $C * * * *$ & Off & $F *$ & Is otope $s * *$ & $C *$ \\
\hline $\begin{array}{l}1630 \\
2 / 23\end{array}$ & 14.8 & --- & N.S. & $\begin{array}{l}1625 \\
2 / 23 \\
\end{array}$ & 14 & $\begin{array}{l}132 \mathrm{Te}-\mathrm{I} \\
133 \mathrm{I}\end{array}$ & $\begin{array}{l}\mathrm{T} \\
\mathrm{T}\end{array}$ & $\begin{array}{l}1620 \\
2 / 23 \\
\end{array}$ & 18 & --- & N.S. & $\begin{array}{l}1615 \\
2 / 23 \\
\end{array}$ & 27 & --- & --- \\
\hline $\begin{array}{l}2400 \\
2 / 23\end{array}$ & 163 & $\begin{array}{l}132 \mathrm{Te}-\mathrm{I} \\
133 \mathrm{I}\end{array}$ & $\begin{array}{l}\mathrm{T} \\
\mathrm{T}\end{array}$ & $\begin{array}{l}2350 \\
2 / 23 \\
\end{array}$ & 173 & $\begin{array}{l}132 \mathrm{Te}-\mathrm{I} \\
133_{\mathrm{I}}\end{array}$ & $\begin{array}{r}5.4 \\
11.2 \\
\end{array}$ & $\begin{array}{l}0520 \\
2 / 24\end{array}$ & 900 & $\begin{array}{l}132 \mathrm{Te}-\mathrm{I} \\
133_{\mathrm{I}}\end{array}$ & $\begin{array}{r}125 \\
73\end{array}$ & $\begin{array}{l}2335 \\
2 / 23\end{array}$ & 8970 & $\begin{array}{l}132_{\mathrm{Te}-\mathrm{I}} \\
133_{\mathrm{I}}\end{array}$ & $\begin{array}{r}15 \\
5.8\end{array}$ \\
\hline $\begin{array}{l}0520 \\
2 / 24 \\
\end{array}$ & 250 & $\begin{array}{l}\text { I3LTe-I } \\
133^{I}\end{array}$ & $\begin{array}{l}\mathrm{T} \\
\mathrm{T}\end{array}$ & $\begin{array}{l}0505 \\
2 / 24 \\
\end{array}$ & 126 & $\begin{array}{l}\text { T32 Te -1 } \\
133_{\mathrm{I}}\end{array}$ & $\begin{array}{l}3.2 \\
6.7 \\
\end{array}$ & $\begin{array}{l}1600 \\
2 / 24 \\
\end{array}$ & 14 & $-\cdots$ & & $\begin{array}{l}0405 \\
2 / 24 \\
\end{array}$ & 1820 & $\begin{array}{l}\mathrm{T} 3 \mathrm{~L}_{\mathrm{Te}-1} \\
133_{\mathrm{I}}\end{array}$ & $\begin{array}{l}7.3 \\
1.6 \\
\end{array}$ \\
\hline $\begin{array}{l}0845 \\
2 / 25 \\
\end{array}$ & 26.4 & -- & N.S. & $\begin{array}{l}1640 \\
2 / 24\end{array}$ & 72 & $\begin{array}{l}132 \mathrm{Te}-\mathrm{I} \\
133_{\mathrm{I}}\end{array}$ & $<1$ & $\begin{array}{l}0830 \\
2 / 25\end{array}$ & 16.6 & $-\cdots$ & & $\begin{array}{l}1700 \\
2 / 24\end{array}$ & 44 & FFP & $\mathrm{T}$ \\
\hline $\begin{array}{l}1630 \\
2 / 25 \\
\end{array}$ & 7 & $\overline{---}$ & N.S. & $\begin{array}{l}0835 \\
2 / 25\end{array}$ & 0.9 & $\begin{array}{l}132 \mathrm{Te}-\mathrm{I} \\
133_{\mathrm{I}}\end{array}$ & $<_{<1}^{1.1}$ & $\begin{array}{l}1645 \\
2 / 25\end{array}$ & 20 & - & & $\begin{array}{l}0825 \\
2 / 25\end{array}$ & 2.5 & FFP & $\mathrm{T}$ \\
\hline $\begin{array}{l}0930 \\
2 / 26 \\
\end{array}$ & 29 & $131 \mathrm{I}$ & $\mathrm{T}$ & $\begin{array}{l}1635 \\
2 / 25 \\
\end{array}$ & 8.8 & $\begin{array}{l}132 \mathrm{Te}-\mathrm{I} \\
133_{\mathrm{I}}\end{array}$ & $\begin{array}{l}\mathrm{T} \\
\mathrm{T}\end{array}$ & $\begin{array}{l}0915 \\
2 / 26 \\
\end{array}$ & 50 & -- & & $\begin{array}{l}1650 \\
2 / 25 \\
\end{array}$ & 21 & -- & $\bar{\cdots}$ \\
\hline $\begin{array}{l}1720 \\
2 / 26 \\
\end{array}$ & 16 & -- & N.S. & $\begin{array}{l}0920 \\
2 / 26 \\
\end{array}$ & 41 & $131_{1}$ & $<1$ & $\begin{array}{l}1705 \\
2 / 26 \\
\end{array}$ & 16.6 & -- & & $\begin{array}{l}0845 \\
2 / 26 \\
\end{array}$ & 82 & $\begin{array}{l}13 I_{I} \\
133_{I}\end{array}$ & $\begin{array}{l}\mathrm{T} \\
\mathrm{T} \\
\end{array}$ \\
\hline $\begin{array}{l}0845 \\
2 / 27 \\
\end{array}$ & 30.8 & $\cdots$ & N.S. & $\begin{array}{l}1710 \\
2 / 26 \\
\end{array}$ & 17 & N.S. & N.S. & $\begin{array}{l}0910 \\
2 / 27 \\
\end{array}$ & 17.2 & $\begin{array}{l}132 \mathrm{Te}-1 \\
133_{\mathrm{I}}\end{array}$ & $\begin{array}{c}\mathrm{T} \\
<0.2 \\
\end{array}$ & $\begin{array}{l}1700 \\
2 / 26\end{array}$ & 32 & $\begin{array}{l}131_{1} \\
133_{1}\end{array}$ & $\begin{array}{l}\mathrm{T} \\
\mathrm{T}\end{array}$ \\
\hline & & & & $\begin{array}{l}0855 \\
2 / 27\end{array}$ & 28.8 & $\begin{array}{l}132 \mathrm{Te}-\mathrm{I} \\
133_{\mathrm{I}}\end{array}$ & $\begin{array}{l}<1 \\
<0.7\end{array}$ & & & & & $\begin{array}{l}0920 \\
2 / 27\end{array}$ & 36 & -- & -- \\
\hline
\end{tabular}

$186^{\circ}$

$20,000^{\prime}$

NOTE: N.S. -- Not significant; T - Trace

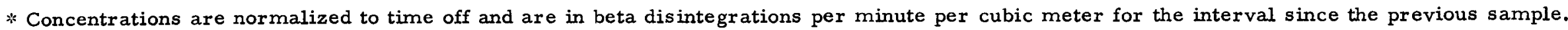
The first sample calculation was based on time since run.

** Is otopes detected on char coal cartridges.

* Concentrations are normalized to time off and are in disintegrations per minute per cubic meter for the interval since the previous sample. No correction applied for leaching of isotopic activity loss. 
Table II (Cont'd.)

A\&E Inside Main Cafeteria

Main Cafeteria Main Gate

$186^{\circ} \quad 20,000^{\circ}$

$171^{\circ} \quad 9300^{\circ}$

$168^{\circ} \quad 16,800^{\prime}$

Rad Safe Check Station

16,800 $167^{\circ}$

\begin{tabular}{|c|c|c|c|c|c|c|c|c|c|c|c|c|c|c|c|}
\hline Off & $F *$ & Isotopes $* *$ & $C * * *$ & Off & $F *$ & Is otopes $* *$ & $C * * * *$ & Off & $F *$ & Isotopes** & $\mathrm{C} * * * *$ & Off & $F *$ & Is otopes $* *$ & $\mathrm{C} * * *$ \\
\hline $\begin{array}{l}1615 \\
2 / 23\end{array}$ & 10 & -- & --- & $\begin{array}{l}1645 \\
2 / 23\end{array}$ & 13.9 & -- & - & $\begin{array}{l}1610 \\
2 / 23\end{array}$ & 26.6 & - & --- & $\begin{array}{l}1550 \\
2 / 23\end{array}$ & 79 & --- & --- \\
\hline $\begin{array}{l}3440 \\
2 / 23 \\
\end{array}$ & 311 & $\begin{array}{l}132 \mathrm{Te}-\mathrm{I} \\
133_{\mathrm{I}}\end{array}$ & $\begin{array}{r}12 . \\
4.6 \\
\end{array}$ & $\begin{array}{l}0030 \\
2 / 24 \\
\end{array}$ & 6560 & $\begin{array}{l}13 Z_{\mathrm{Te}-\mathrm{I}} \\
133_{\mathrm{I}}\end{array}$ & $\begin{array}{r}320 \\
1700 \\
\end{array}$ & $\begin{array}{l}2330 \\
2 / 23 \\
\end{array}$ & 10000 & $\begin{array}{l}132_{\mathrm{Te}-\mathrm{I}} \\
133_{\mathrm{I}}\end{array}$ & $\begin{array}{r}33 \\
120 \\
\end{array}$ & $\begin{array}{l}1810 \\
2 / 23\end{array}$ & 1228 & $\begin{array}{l}\text { 132 Te-I } \\
133_{\mathrm{I}}\end{array}$ & $\begin{array}{l}\mathrm{T} \\
\mathrm{T}\end{array}$ \\
\hline $\begin{array}{l}0400 \\
2 / 24 \\
\end{array}$ & 800 & $\begin{array}{l}132 \mathrm{Te}-\mathrm{I} \\
133_{\mathrm{I}}\end{array}$ & $\begin{array}{l}3 \\
4.7 \\
\end{array}$ & $\begin{array}{l}0415 \\
2 / 24\end{array}$ & 1700 & $\begin{array}{l}132 \mathrm{Te}-\mathrm{I} \\
133_{\mathrm{I}}\end{array}$ & $\begin{array}{r}48 \\
200 \\
\end{array}$ & $\begin{array}{l}0350 \\
2 / 24 \\
\end{array}$ & 2300 & $\begin{array}{l}132 \mathrm{Te}-\mathrm{I} \\
133_{\mathrm{I}}\end{array}$ & $\begin{array}{l}28 \\
78 \\
\end{array}$ & $\begin{array}{l}1925 \\
2 / 23\end{array}$ & 21022 & $\begin{array}{l}132 \mathrm{Te}-\mathrm{I} \\
133_{\mathrm{I}}\end{array}$ & $\begin{array}{l}27 \\
4173\end{array}$ \\
\hline $\begin{array}{l}1700 \\
2 / 24\end{array}$ & 28 & $\begin{array}{l}\text { I3LTe-I } \\
133 \mathrm{I}\end{array}$ & $\begin{array}{l}3.6 \\
1.8\end{array}$ & $\begin{array}{l}1620 \\
2 / 24\end{array}$ & 33 & $\begin{array}{l}\text { 132 Te-I } \\
133 \mathrm{I}\end{array}$ & $\begin{array}{r}9 \\
50 \\
\end{array}$ & $\begin{array}{l}1710 \\
2 / 24 \\
\end{array}$ & 66 & - & $\cdots$ & $\begin{array}{l}2125 \\
2 / 23 \\
\end{array}$ & 1628 & -- & -- \\
\hline $\begin{array}{l}0825 \\
2 / 25 \\
\end{array}$ & 8.8 & - & -- & $\begin{array}{l}0855 \\
2 / 25 \\
\end{array}$ & 8.5 & $\begin{array}{l}13 \mathrm{~L}_{\mathrm{Te}-\mathrm{I}} \\
133_{\mathrm{I}}\end{array}$ & $\begin{array}{r}6 \\
13 \\
\end{array}$ & $\begin{array}{l}0815 \\
2 / 25 \\
\end{array}$ & 11 & - & -- & $\begin{array}{l}2325 \\
2 / 23 \\
\end{array}$ & 3000 & $\begin{array}{l}\text { I3L Te-I } \\
133_{\mathrm{I}}\end{array}$ & $\begin{array}{l}5 \\
T\end{array}$ \\
\hline $\begin{array}{l}1650 \\
2 / 25 \\
\end{array}$ & 8.1 & - & -- & $\begin{array}{l}1625 \\
2 / 25 \\
\end{array}$ & 7 & $\begin{array}{l}132 \mathrm{Te}-\mathrm{I} \\
133_{\mathrm{I}}\end{array}$ & $\begin{array}{l}20 \\
86\end{array}$ & $\begin{array}{l}1655 \\
2 / 25\end{array}$ & 13 & -- & $-\infty$ & $\begin{array}{l}0230 \\
2 / 24\end{array}$ & 350 & -- & -- \\
\hline $\begin{array}{l}0845 \\
2 / 26 \\
\end{array}$ & 18 & -- & -- & $\begin{array}{l}0935 \\
2 / 26\end{array}$ & 136 & $\begin{array}{l}\text { I3II } \\
132_{\mathrm{Te}-\mathrm{I}}\end{array}$ & $\begin{array}{r}280 \\
94\end{array}$ & $\begin{array}{l}1650 \\
2 / 26 \\
\end{array}$ & 25.6 & -- & $\cdots$ & $\begin{array}{l}0450 \\
2 / 24 \\
\end{array}$ & 206 & $\begin{array}{l}132 \mathrm{Te}-\mathrm{I} \\
133_{\mathrm{I}}\end{array}$ & $\begin{array}{l}T \\
5.7\end{array}$ \\
\hline $\begin{array}{l}1700 \\
2 / 26 \\
\end{array}$ & 10 & $\cdots$ & - & 1730 & 25 & $\frac{133^{I}}{132 \mathrm{Te}-\mathrm{I}}$ & $\frac{460}{8.6}$ & $\begin{array}{l}0930 \\
2 / 27 \\
\end{array}$ & 42.9 & - & - & $\begin{array}{l}0730 \\
2 / 24\end{array}$ & 56 & -- & -- \\
\hline $\begin{array}{l}0920 \\
2 / 27 \\
\end{array}$ & 12.6 & $\overline{--}$ & -- & $\begin{array}{l}2 / 26 \\
0835 \\
2 / 27\end{array}$ & 23.8 & $\frac{133 \mathrm{I}}{132 \mathrm{Te}-\mathrm{I}}$ & $\frac{12}{2.5}$ & & & & & $\begin{array}{l}1600 \\
2 / 24\end{array}$ & 11 & --- & $\cdots$ \\
\hline & & & & $2 / 27$ & & & 4 & & & & & $\begin{array}{l}2115 \\
2 / 24\end{array}$ & 1.3 & -- & -- \\
\hline
\end{tabular}

NOTE: T -- Trace

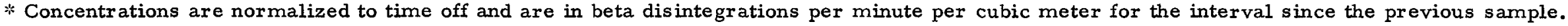

The first sample calculation was based on time since run.

** Is otopes detected on charcoal cartridges.

*** Concentrations are normalized to time off and are in disintegrations per minute per cubic meter for the interval since the previous sample.

No correction applied for leaching of isotopic activity loss. 
Table III

PHOEBUS IB EP-II

TEST CELL “C" RADIATION SURVEY RESUL TS *

\begin{tabular}{|c|c|c|c|c|c|c|c|c|c|c|c|c|c|c|c|c|c|c|c|c|c|c|c|c|c|c|c|c|c|}
\hline DATE & TIME & 1 & 2 & 3 & 4 & 5 & 6 & 7 & 8 & 9 & 10 & 11 & 12 & 13 & 14 & 15 & 16 & 17 & 18 & 19 & 20 & 21 & 22 & 23 & 24 & 25 & 26 & 27 & 28 \\
\hline $2 / 10$ & 1400 & 30 & & & & & & & & & & & & & & & & & & & & & & & & & & & \\
\hline $2 / 10$ & 1545 & 27 & & & & & & & & & & & & & & & & & & & 20 & & & & & & & & \\
\hline $2 / 10$ & 1723 & 18 & 2 & 130 & 29 & 30 & 40 & 74 & 160 & 200 & 75 & 180 & 115 & 300 & 115 & 620 & 600 & 310 & 340 & 88 & 7 & 86 & 140 & 440 & 41 & 12 & 1 & 260 & 23 \\
\hline $2 / 10$ & 2110 & 6 & 2 & 56 & 13 & 12 & 15 & 27 & 42 & 40 & 22 & 40 & 30 & 72 & 30 & 180 & 200 & 140 & 120 & 38 & 4 & 36 & 38 & 150 & 14 & 6 & 1 & 80 & 12 \\
\hline $2 / 10$ & 2254 & 6 & 2 & 48 & 12 & 10 & 9 & 17 & 23 & 34 & 20 & 33 & 21 & 55 & 27 & 170 & 160 & 83 & 70 & 30 & 5 & 24 & 35 & 145 & 13 & 5 & 1 & 52 & 8 \\
\hline $2 / 11$ & 0100 & 6 & Bkgd. & 38 & 12 & 8 & 8 & 12 & 18 & 25 & 11 & 20 & 15 & 40 & 20 & 74 & 54 & 57 & 35 & 27 & 8 & 19 & 23 & 68 & 13 & 6 & 2 & 24 & 6 \\
\hline $2 / 11$ & 0924 & 3 & Bkgd. & 27 & 6 & 4 & 4 & 5 & 7 & 9 & 4 & 12 & 5 & 16 & 11 & 31 & 38 & 24 & 8 & 10 & 3 & 6 & 7 & 28 & 4 & 2 & 2 & 8 & 5 \\
\hline $2 / 12$ & 0323 & & & 12 & & & & & & & & & & 8 & & 16 & 18 & 13 & & & & & & 13 & & & & & \\
\hline $2 / 12$ & 0909 & & & 11 & & & & & & & & & & 8 & & 12 & 15 & 10 & & & & & & 10 & & & & & \\
\hline $2 / 12$ & 1720 & & & 8 & & & & & & & & & & 5 & & 6 & 10 & 8 & & & & & & 8 & & & & & \\
\hline
\end{tabular}

* RESULTS ARE IN mR/hr.

* 1 . Main Gate

2. Inside Field Station at Control Console

3. Ground Water Tank Valve 6255

4. Cooling Tower Valve

5. Air Intake Building Door - Outside

6. $\mathrm{LN}_{2}$ Off-Loading - East

7. Between Dewars 4 \& 5 at RAM \#31

8. Top of Dewar \#5

9. Top of East Walkway over Flare Line

10. Between Tank Farm and High Pressure Room

11. Edge of Test Cell Face - East Wall

12. Outside High Pressure Room Door

13. Top of Flow Control Roof Stairs

14. Outside Neutronics Room Door

15. Bottom of Penthouse - East Stairs

16. Top of South Stairs of Penthouse Roof

17. Center Propellant Room Roof

18. Between Dewars 1 \& 2 at L 3 Valve on Catwalk

19. South, Outside Door of FCR Room

20. Hook -up Room

21. Outside Pump Room South Door

22. Between Dewars 1 \& 2 at Ground Level

23. Wing Wall, Northwest Corner

24. $\mathrm{LH}_{2}$ Loading Station - New Dewar Pad

25. Privy Pit Door - Inside

26. Privy Pit Door - Outside

27. Privy Pit - Inside at Center

28. North Edge of Privy - Inside 
Table IV

PHOEBUS IB POST EP-IV

TEST CELL "C" RADIATION SURVEY RESULTS *

\begin{tabular}{|c|c|c|c|c|c|c|c|c|c|c|c|c|c|c|c|c|c|c|c|c|c|c|c|c|c|c|c|c|c|}
\hline DATE & TIME & 1 & 2 & 3 & 4 & 5 & 6 & 7 & 8 & 9 & 10 & 11 & 12 & 13 & 14 & 15 & 16 & 17 & 18 & 19 & 20 & 21 & 22 & 23 & 24 & 25 & 26 & 27 & 28 \\
\hline $2 / 24$ & 1300 & & & & & & & & & & & & & & & & & & & 23000 & 80 & 2000 & & & & & & & \\
\hline $2 / 25$ & 1700 & & & & & & 200 & & & & & & & & & & & & & & & & & & & & & & \\
\hline $2 / 26$ & 1430 & 40 & 2 & 80 & 50 & 32 & 75 & 150 & & 220 & 540 & 150 & 1100 & 4500 & & 3000 & & & & 5800 & 14 & 200 & 1000 & 600 & 70 & & 1 & & \\
\hline $2 / 28$ & 0830 & 15 & 2 & 17 & 19 & 13 & 34 & 68 & 160 & 140 & 260 & & 780 & 2000 & 6000 & & & & 64 & 3000 & & 140 & 470 & 460 & & & & & \\
\hline $2 / 28$ & 1035 & & & & & & & & & & & & & & & & & & & & & & 280 & 445 & 40 & & & & \\
\hline $2 / 28$ & 1050 & & & & & & & & & & & 750 & 700 & & & & & & & 3000 & & 120 & & 680 & & & & & $\star \star \star *$ \\
\hline $2 / 28$ & 1145 & & & & & & & & & & & & & & & & & & & 3000 & & & & 680 & & & & & 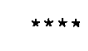 \\
\hline $2 / 28$ & 1310 & 14 & 1 & 14 & 17 & 11 & 30 & 52 & 170 & 140 & 290 & 42 & 640 & 1800 & 4600 & 1000 & 104 & 2000 & 50 & 400 & 34 & 84 & 380 & 400 & 32 & 4 & 4 & 16 & 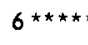 \\
\hline $3 / 1$ & 1935 & & & & & & & & & & & & & 1800 & 1300 & & 500 & 800 & & & & & & & & & & & \\
\hline $3 / 2$ & 1130 & & & & & & & & & & & & & 1500 & 650 & & 400 & 180 & & & & & & & & & & & \\
\hline $3 / 2$ & 2245 & & & & & & & & & & & & & 700 & 300 & & 400 & 190 & & & & & & & & & & & \\
\hline $3 / 3$ & 1115 & & & & & & & & & & & & & 1000 & 560 & & & 200 & & & & & & & & & & & \\
\hline $3 / 6$ & 0800 & 6 & 4 & & & & & & & & & & & & & & & & & & & & & & & & & & \\
\hline $3 / 7$ & 1115 & 5 & 1 & 4 & 10 & 20 & 35 & 100 & 30 & 100 & 175 & 45 & 320 & 500 & & & & 40 & 20 & 200 & & 50 & 40 & 100 & 14 & & & & \\
\hline $3 / 8$ & 0115 & 5 & 1 & 4 & 40 & 58 & 50 & 100 & & 240 & $35^{\circ}$ & 180 & 40 & 400 & 260 & 120 & 120 & 30 & 20 & 820 & & 226 & 26 & 30 & 10 & & & & \\
\hline $3 / 10$ & 0130 & & & & & & & & & & & & & & 200 & & & & & & & & & & & & & & \\
\hline $3 / 13$ & & 2 & & 4 & 4 & 8 & 22 & 32 & 14 & 30 & 13 & 13 & 70 & 120 & 150 & 48 & 180 & 16 & 8 & 170 & & 18 & 20 & 41 & 7 & & & & \\
\hline $3 / 15$ & 1800 & 4 & $<1$ & 6 & 6 & & & 15 & & & 20 & & 70 & 110 & 130 & 55 & 88 & 27 & 11 & 100 & & 10 & 15 & & 5 & & & & \\
\hline $3 / 20$ & 0730 & 3 & $<1$ & 4 & 4 & 4 & 4 & 6 & & 22 & 12 & 20 & 60 & 50 & 70 & 35 & 60 & 18 & & 80 & 1 & 34 & 8 & & 4 & & & & \\
\hline $3 / 27$ & 2130 & 2 & & 2 & 4 & 5 & 6 & 16 & & & & 14 & 40 & & & & & & & & & & & 16 & & & & & \\
\hline $4 / 3$ & 0615 & 1 & & $<1$ & $<1$ & & 2 & & & 41 & 6 & 5 & 22 & 40 & 60 & 26 & 26 & & & 32 & & & & & & & & & \\
\hline $4 / 10$ & 0630 & 1 & & 3 & 2 & 2 & 6 & 4 & & 3 & 3 & 4 & 22 & 32 & 40 & 18 & 30 & 18 & 6 & 32 & & 6 & 4 & 14 & 4 & & & & \\
\hline
\end{tabular}

* RESUL TS ARE IN $\mathrm{mR} / \mathrm{hr}$ 。

** SEE TABLE III FOR DESCRIPTION OF SURVEY LOCATION $\star \star \star$ SHIELD DRAINED AND OPENED l'

$\star \star \star \star$ SHIELD OPEN WIDE

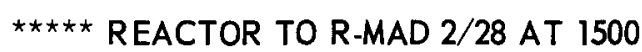


Table Y

PAD DECAY SURVEY RADIA TION MEASUREMENTS : POST-PHOEBUS IB EP II PHASE II

\begin{tabular}{|c|c|c|c|c|c|c|c|c|c|c|c|c|c|c|c|c|c|c|}
\hline \multirow{2}{*}{$\begin{array}{l}\text { Time After } \\
\text { hutdown, Hrs }\end{array}$} & \multicolumn{7}{|c|}{ NORTH } & \multicolumn{5}{|c|}{ EAST } & \multicolumn{5}{|c|}{ WEST } & \multirow[b]{2}{*}{ Remarks } \\
\hline & $20^{1}$ & $40^{\prime}$ & $60^{\prime}$ & $80^{\prime}$ & $100^{1}$ & $120^{\prime}$ & $140^{\prime}$ & $20^{\prime}$ & $40^{\prime}$ & $60^{\prime}$ & $80^{\prime}$ & $100^{\prime}$ & $20^{\prime}$ & $40^{\prime}$ & $60^{\prime}$ & $80^{\prime}$ & $100^{\prime}$ & \\
\hline 0.5 & & & & & & & & & & & & & 410 & 350 & 150 & 73 & 47 & Shield Closed \\
\hline 0.7 & 740 & 320 & 140 & 60 & 40 & 27 & 18 & 380 & 310 & 160 & 72 & 46 & & & & & & \\
\hline 1.2 & 340 & 150 & 66 & 32 & 19 & 12 & 9 & 160 & 140 & 56 & 30 & 19 & 190 & 160 & 154 & 31 & 17 & \\
\hline 2.6 & 140 & 53 & 22 & 12 & 8 & 6 & 4 & 62 & 51 & 22 & 14 & 8 & 64 & 48 & 18 & 12 & 6 & \\
\hline 5.9 & 2200 & 415 & 200 & 98 & 58 & 40 & 28 & 330 & 66 & 30 & 16 & 8 & 315 & 86 & 24 & 13 & 9 & Shield Open \\
\hline 18.9 & 200 & 65 & 28 & & & & & & & & & & & & & & & \\
\hline 21.2 & - & 36 & 18 & & & & & 28 & 8 & 3 & & & 25 & 8 & 2 & & & Shed locked \& sealed \\
\hline 25 & - & 27 & 13 & & & & & 21 & 6 & 3 & & & 18 & 4 & 1 & & & \\
\hline 32.7 & - & 20 & 8 & & & & & 10 & 4 & 1 & & & 10 & 6 & 2 & & & \\
\hline 36.7 & - & 18 & 10 & & & & & 14 & 5 & 2 & & & 12 & 4 & 2 & & & Shield Drained \& Open \\
\hline 41.7 & - & 17 & 9 & & & & & 13 & 4 & 1 & & & 11 & 4 & 1 & & & \\
\hline 45.4 & - & 14 & 7 & & & & & 8 & 4 & 2 & & & 10 & 4 & 2 & & & \\
\hline 48.9 & $=$ & 11 & 6 & & & & & 7 & 3 & 2 & & & 8 & 2 & 1 & & & \\
\hline 55.2 & - & 11 & 6 & & & & & 8 & 4 & 1 & & & 7 & 2 & 1 & & & \\
\hline 59.7 & - & 11 & 5 & & & & & 5 & 2 & 1 & & & 5 & 3 & 1 & & & \\
\hline 67.4 & - & 10 & 5 & & & & & 7 & 4 & 1 & & & 9 & 4 & 1 & & & \\
\hline 77.4 & 20 & 8 & 3 & & & & & 10 & 3 & - & & & 6 & 2 & - & & & Shed Removed. \\
\hline & & & & & & & & & & & & & & & & & & \\
\hline & & & & & & & & & & & & & & & & & & \\
\hline & & & & & & & & & & & & & & & & & & \\
\hline
\end{tabular}

* Measurements are in $\mathrm{mR} / \mathrm{hr}$.

NOTE: Distances are from reactor centerline.

Shutdown effected at 1117 on $2 / 3 / 67$. 
Table VI

PAD DECAY SURVEY RADLATION MEASUREMENTS *

POST-PHOEBUS IB EP III

\begin{tabular}{|c|c|c|c|c|c|c|c|c|c|c|c|c|c|c|c|c|c|c|}
\hline \multirow{2}{*}{$\begin{array}{l}\text { Time After } \\
\text { hutdown, } \mathrm{Hr}\end{array}$} & \multicolumn{7}{|c|}{ NORTH } & \multicolumn{5}{|c|}{ EAST } & \multicolumn{5}{|c|}{ WEST } & \multirow[b]{2}{*}{ Remarks } \\
\hline & $20^{\prime}$ & $40^{\prime}$ & $60^{\prime}$ & $80^{\prime}$ & $100^{\prime}$ & $120^{\prime}$ & $140^{\prime}$ & $20^{\prime}$ & $40^{\prime}$ & $60^{1}$ & $80^{\prime}$ & $100^{\prime}$ & $20^{\prime}$ & $40^{\prime}$ & $60^{\prime}$ & $80^{\prime}$ & $100^{\prime}$ & \\
\hline 9.7 & 6000 & 2100 & & & & & & 6000 & 2100 & 1000 & & & 6000 & 2100 & 1000 & & & \\
\hline 11.2 & 3300 & 1300 & 760 & & & & & 1400 & 1400 & 860 & & & 1200 & 1200 & 710 & & & \\
\hline 20.2 & 1000 & 520 & 260 & & & & & 680 & 550 & 260 & & & 580 & 500 & 260 & & & \\
\hline 44,1 & 300 & 150 & 60 & 37 & 29 & 24 & 20 & 160 & 150 & 63 & 40 & 28 & 160 & 160 & 50 & 28 & 20 & \\
\hline 52.2 & 260 & 94 & 52 & 32 & 22 & 16 & 14 & 200 & 100 & 46 & 30 & 20 & 160 & 96 & 38 & 22 & 14 & \\
\hline 90.2 & 120 & 58 & 28 & 14 & 8 & & & 60 & 54 & 23 & 13 & 8 & 58 & 57 & 22 & 10 & 6 & \\
\hline 101.7 & $=$ & 44 & 18 & 10 & 4 & 2 & 1 & 72 & 42 & 17 & 9 & 5 & 74 & 44 & 16 & 8 & 5 & \\
\hline 114.2 & 130 & 44 & 20 & 10 & 6 & & & 52 & 39 & 18 & 10 & 7 & 52 & 46 & 18 & 10 & 6 & \\
\hline 170.7 & 115 & 47 & 21 & 12 & 9 & 6 & 4 & 53 & 37 & 18 & 12 & 7 & 50 & 45 & 19 & 11 & 8 & \\
\hline $184 . ?$ & - & 44 & 20 & & & & & 54 & 42 & 18 & & & 52 & 42 & 18 & & & \\
\hline 200.7 & - & 50 & 25 & & & & & 50 & 35 & 20 & & & 50 & 40 & 18 & & & \\
\hline 208,9 & 88 & 32 & 16 & & & & & 36 & 29 & 16 & & & 37 & 32 & 14 & & & \\
\hline 221.7 & 98 & 32 & 13 & & & & & 34 & 28 & 14 & & & 34 & 28 & 10 & & & \\
\hline 232.7 & 46 & 28 & 12 & & & & & 43 & 26 & 12 & & & 38 & 26 & 10 & & & \\
\hline & \\
\hline & & & & & & & & & & & & & & & & & & \\
\hline & & & & & & & & & & & & & & & & & & \\
\hline & & & & & & & & & & & & & & & & & & \\
\hline & & & & & & & & & & & & & & & & & & \\
\hline & & & & & & & & & & & & & & & & & & \\
\hline
\end{tabular}

* Measurements are in $\mathrm{mR} / \mathrm{hr}$.

NOTE: Distances are from reactor centerline.

Shutdown effected at 1315 on 2/10/67. 
Table VII

PAD DECAY SURVEY RADIATION MEASUREMENTS * POST-PHOEBUS IB EP IV

\begin{tabular}{|c|c|c|c|c|c|c|c|c|c|c|c|c|c|c|c|c|c|c|}
\hline \multirow{2}{*}{$\begin{aligned} & \text { Time After } \\
&= \text { hutdown, Hrs } \\
&\end{aligned}$} & \multicolumn{7}{|c|}{ NORTH } & \multicolumn{5}{|c|}{ EAST } & \multicolumn{5}{|c|}{ WEST } & \multirow[b]{2}{*}{ Remarks } \\
\hline & 201 & $40^{\prime}$ & $60^{\prime}$ & $80^{\prime}$ & $100^{\prime}$ & $120^{\prime}$ & $140^{\prime}$ & $20^{\prime}$ & $40^{\prime}$ & $60^{\prime}$ & $80^{\prime}$ & $100^{\prime}$ & $20^{\prime}$ & $40^{\prime}$ & $60^{\prime}$ & $80^{\prime}$ & $100^{\prime}$ & \\
\hline 113.4 & & & & & 6000 & 4400 & 3200 & & 2600 & 2100 & 1300 & 1400 & & 4000 & 1100 & 1000 & 520 & Shed Out \\
\hline 116.1 & & & & & & & & & & & & & & 4700 & 1200 & 1000 & & Shield Drained \&close \\
\hline 116.2 & & & & & & & & & 8800 & 5000 & 2600 & 1700 & & $10000+$ & 3800 & 2200 & 700 & Shield Drained \& open 1 \\
\hline 117.1 & & & & & & & & & & & & & & & 4500 & & & Shield Drained sropep \\
\hline 118.6 & & & Great & er than & 10000 a & $50^{\prime}$ & & & & & & & & 3000 & 740 & 640 & & wide \\
\hline \multirow[t]{2}{*}{121.9} & & & & & & & & & & & & 1000 & & & & & & Reactor to $R-M A D$ on \\
\hline & & & & & & & & & & & & & & & & & & $.2 / 28$ at 1500 \\
\hline 164.1 & 9000 & & & & & & & & & & & & & & & & & \\
\hline 176.2 & 1500 & & & & & & & 2000 & & & & & 4000 & & & & & \\
\hline 300.1 & 1000 & 800 & 600 & 660 & 12000 & & & 1400 & 310 & 380 & 280 & 260 & 1200 & 660 & 200 & 200 & 160 & \\
\hline 452.6 & 760 & 510 & 420 & 500 & 6000 & 1400 & 840 & 540 & 70 & 90 & 90 & 450 & 950 & 280 & 50 & 50 & 30 & \\
\hline 602.9 & 230 & 260 & 220 & 310 & 2500 & & & 200 & 37 & 32 & & & 80 & 40 & 22 & & & \\
\hline 652.1 & 200 & 230 & 175 & & 680 & & & 115 & 30 & 25 & & & 75 & 40 & 20 & & & \\
\hline & & & & & & & & & & & & & & & & & & \\
\hline & & & & & & & & & & & & & & & & & & \\
\hline & & & & & & & & & & & & & & & & & & \\
\hline & & & & & & & & & & & & & & & & & & \\
\hline & & & & & & & & & & & & & & & & & & \\
\hline & & & & & & & & & & & & & & & & & & \\
\hline
\end{tabular}

* Measurements are in $\mathrm{mR} / \mathrm{hr}$.

NOTE: Distances are from reactor centerline.

Shutdown effected at 1434 on $2 / 23 / 67$. 
Table VIII

PHOEBUS IB REACTOR TEST SERIES

WEEKLY CUMULATIVE EXPOSURES AT TEST CELL "C"

Week Ending

$1 / 27$

$2 / 3$

$2 / 10$

$2 / 17$

$2 / 24$

$3 / 3$

$3 / 10$

$3 / 17$

$3 / 24$

$3 / 31$

TOTAL
Cumulative Weekly Dose, $m R$ Monitors Other *

$\begin{array}{rr}65 & 180 \\ 235 & 4,470 \\ 810 & 800 \\ 500 & 3,525 \\ 695 & 2,695 \\ 5,180 & 5,710 \\ 4,095 & 39,520 \\ 1,585 & 20,915 \\ 520 & 12,075 \\ 375 & 8,590 \\ 14,060 & \\ & 98,480\end{array}$

*Other includes all personnel who are not monitors. 
A P P E N D I X

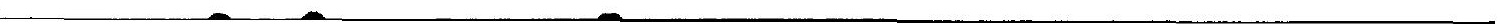


EP-I Phase 1

DATE - JANUARY 25, 1967, Shutdown at 1408

Monitoring Assignment

Initial Survey

Drums Lock

Nozzle Survey

(Shield Open \&

Drained)
Survey Location

West $2^{\prime}$ from Cart

North Edge of Cart

East $2^{\prime}$ from Cart

3' above Privy Roof at contact with shield

Outside Privy Door

Inside Privy

Contact at Nozzle Top

1' from Nozzle Top

Contact at Nozzle Throat

West at 1 meter from Nozzle Throat

West at $18^{\prime \prime}$ from Nozzle

Bottom

Dose Rate, $\mathrm{mR} / \mathrm{hr}$, OW

50

65

40

2200

20

10

1000

600

1500

700

3500

1840

(4.5)

from inside Reactor

Shield

Average Dose Rate for

Removal

Max. Dose Rate at contact

with shield's mid plane

3500

8500

North Edge of Car

EP-I Phase 2

DATE - JANUARY 26, 1967, Shutdown at 1630

Initial Survey

1650

$(0.3)$
West Wing Wall

West Privy Door

18

North End of Reactor Car

East Privy Door

$60^{\prime}$ North, West and East

of Reactor

\section{0}

80

30

10

NOTE: Numbers in parentheses represent the approximate time in hours after nuclear shutdown. 


\section{Monitoring Assignment}

Drums Lock

Pad Survey

DATE - JANUARY 28, 1967

General Survey

0815

(39.7)
Survey Location

West Wing Wall

West Privy Door

Inside Privy

$30 '$ North

20' East and West
Dose Rate $\mathrm{mR} / \mathrm{hr}$, OW

10

20

10

10

10

Elephant Gun, Max. $\quad 50$

Elephant Gun, Av'g. $\quad 20$

Reactor Midplane, contact $\quad 630$

Annulus, $A v^{\prime} g$.

300

Inside Privy

DATE - JANUARY 29, 1967

General Survey

0630

Elephant Gun, Max. 40

Elephant Gun, Av'g.

Reactor Midplane, contact

Reactor Midplane, $2^{\prime}$

Inside Privy

DATE - JANUARY 31, 1967

General Survey

0745

(111.2)

Reactor Midplane, contact

Rear Deck of Car

260

Front Deck of Car

DATE - FEBRUARY 1, 1967

0745

Reactor Midplane, contact

EP-II, Phase 1

(135.2)

DATE - FEBRUARY 2, 1967, Shutdown at 1815

$100 \mathrm{mR} / \mathrm{hr}$ Line

1845

$(0.5)$

$10 \mathrm{mR} / \mathrm{hr}$ Line

2' West of Privy

100

2' East of Privy

100

25' North of Privy

100

$80^{\prime}$ West of Privy

10

(0.5) 


\begin{tabular}{|c|c|c|c|}
\hline Monitoring Assignment & Time & Survey Location & $\begin{array}{l}\text { Dose Rate } \\
\mathrm{mR} / \mathrm{hr} \text {. OW }\end{array}$ \\
\hline \multirow[t]{8}{*}{ Rods Team } & 1850 & West Wing Wall & 14 \\
\hline & $(0.6)$ & Outside Privy Door & 20 \\
\hline & & West Shed Track & 28 \\
\hline & & Inside Privy & 14 \\
\hline & 1907 & Pump Room & Bkgd. \\
\hline & $(0.9)$ & Flow Control Room & Bkgd. \\
\hline & & Hook-up Room & Bkgd. \\
\hline & $\begin{array}{l}1915 \\
(1.0)\end{array}$ & Reactor Elect. Pit & 2 \\
\hline \multirow[t]{15}{*}{ J-5 Shutdown } & 1900 & Midplane between & \\
\hline & $(0.8)$ & Dewars $1 \& 2$ & 4 \\
\hline & 1910 & Outside Neutronics Shed & \\
\hline & $(0.9)$ & Door & 4 \\
\hline & 1920 & Base $\mathrm{LN}_{2}$ Dewar & 3 \\
\hline & 1940 & Neutronics Shed Roof- & \\
\hline & & Shielded & 6 \\
\hline & 1940 & $\begin{array}{l}\text { Neutronics Shed Roof- } \\
\text { Unshielded }\end{array}$ & 14 \\
\hline & 1940 & $20^{\prime}$ N., $E \& W$ of & \\
\hline & & Reactor & 40 \\
\hline & 1950 & Max. Unshielded on & \\
\hline & & Neutronics Shed Roof & 30 \\
\hline & 1950 & Outside W. Privy Door & 20 \\
\hline & 1950 & Privy Inside & 15 \\
\hline & $\begin{array}{l}2000 \\
(1.7)\end{array}$ & $60^{\prime} \mathrm{W}$. of Reactor & 3 \\
\hline
\end{tabular}

EP-II Phase 2

DATE - FEBRUARY 3, 1967, Shutdown at 1117

Dose Rate Lines $\quad 1150$

$(0.5)$

$\begin{array}{ll}230^{\prime} \mathrm{W} \text {. of Reactor } & 10 \\ 233^{\prime} \mathrm{E} \text {. of Reactor } & 10 \\ 250^{\prime} \mathrm{N} \text {. of Reactor } & 10 \\ 95^{\prime} \mathrm{W} \text {. of Reactor } & 100 \\ 90^{\prime} \mathrm{E} \text {. \& N. of Reactor } & 100 \\ 30^{\prime} \mathrm{W} \text {. \& N. of Reactor } & 1000 \\ 300^{\prime} \mathrm{S} \text {. of Reactor } & 1 \\ 200^{\prime} \mathrm{S} \text {. of Reactor } & 2 \\ 100^{\prime} \mathrm{S} \text {. of Reactor } & 6\end{array}$

Rods Team 1153

(0.6)

West Wing Wall 280

Privy Door 200

W. Shed Track $\quad 580$

Inside Privy 220 


\begin{tabular}{|c|c|c|c|}
\hline Monitoring Assignment & Time & Survey Location & $\begin{array}{l}\text { Dose Rate } \\
\mathrm{m} \mathrm{R} / \mathrm{kr}, \mathrm{OW}\end{array}$ \\
\hline Rods Team & $\begin{array}{l}1200 \\
(0.7)\end{array}$ & $\begin{array}{l}\text { Flow Control Room } \\
\text { Pump Room } \\
\text { Hook-up Room }\end{array}$ & $\begin{array}{l}\text { Bkgd. } \\
\text { Bkgd. } \\
\text { Bkgd. }\end{array}$ \\
\hline $\mathrm{J}-5$ Team & $\begin{array}{l}1200 \\
1212 \\
1221 \\
1222 \\
(1.1) \\
\\
1300 \\
(1.7) \\
1302\end{array}$ & $\begin{array}{l}\text { Between Dewars } 1 \& 2 \\
\text { Midplane } \\
\text { West Wing Wall } \\
\text { Neutronics Shed Roof, } \\
\text { Shielded } \\
\text { Neutronics Shed Roof, } \\
\text { Unshielded } \\
\\
\text { Neutronics Shed Roof, } \\
\text { Shielded } \\
\text { Neutronics Shed Roof, } \\
\text { Unshielded }\end{array}$ & $\begin{array}{l}6 \\
180 \\
26 \\
200 \text { avg. } \\
600 \text { max. } \\
12 \\
400 \text { max. }\end{array}$ \\
\hline Special & $\begin{array}{l}1215 \\
1219 \\
1220 \\
1322 \\
1323\end{array}$ & $\begin{array}{l}\text { Borated Water Tank } \\
\mathrm{LH}_{2} \text { Fill Station } \\
\text { TC"C" Main Gate } \\
\text { N. Reactor Shield at } \\
\text { Crack, Midplane } \\
\text { W. Reactor Shield at } \\
\text { Crack, Midplane }\end{array}$ & $\begin{array}{l}2 \\
1 \\
\text { Bkgd. } \\
24,500 \\
16,000\end{array}$ \\
\hline Dose Rate Lines & $\begin{array}{l}1230 \\
(1.2)\end{array}$ & $\begin{array}{l}130^{\prime} \mathrm{W}, \mathrm{N} \& \mathrm{E} \text { of Reactor } \\
50^{\prime} \mathrm{W}, \mathrm{N} \& \mathrm{E} \text { of Reactor } \\
20^{\prime} \mathrm{W} \text { of Reactor } \\
20^{\prime} \mathrm{N} \text { of Reactor } \\
20^{\prime} \mathrm{E} \text { of Reactor } \\
100^{\prime} \mathrm{S} \text { of Reactor }\end{array}$ & $\begin{array}{l}10 \\
100 \\
190 \\
340 \\
160 \\
1\end{array}$ \\
\hline Rabbit Recovery & $\begin{array}{l}1315 \\
(2)\end{array}$ & $\begin{array}{l}\text { Reactor Pit } \\
\text { Rabbit at Contact } \\
\text { Rabbit at } 21\end{array}$ & $\begin{array}{l}3 \\
140 / 100 * \\
2\end{array}$ \\
\hline Dose Rate Lines & $\begin{array}{l}1400 \\
(2.7)\end{array}$ & $\begin{array}{l}20^{\prime} \mathrm{W} \& \mathrm{E} \text { of Reactor } \\
30^{\prime} \mathrm{N} \text { of Reactor }\end{array}$ & $\begin{array}{l}100 \\
100\end{array}$ \\
\hline N-2 Wire Removal & $\begin{array}{c}1420 \\
(3)\end{array}$ & $\begin{array}{l}\text { Top of Shield, E. Side } \\
\text { Middle of Shield, NE } \\
\text { Side } \\
\text { Middle of Shield, SE } \\
\text { Side } \\
\text { Contact with Wire }\end{array}$ & $\begin{array}{l}2000 \\
1000 \\
1000 \\
600\end{array}$ \\
\hline
\end{tabular}

DATE: FEBRUARY 6, 1967 
Monitoring Assignment

General Survey

0750

(68.5)
Survey Location

N. , Top of Privy Roof

N. Center of Cart Deck

S. Center of Cart Deck
Dose Rate $m / \mathrm{hr}, \mathrm{OW}$

DATE: FEBRUARY 7, 1967

General

N. Edge of Reactor Cart

N., Top of Privy Roof

N. Center of Cart Deck

S. Center of Cart Deck

DATE: FEBRUARY 8, 1967

General Survey

N. Edge of Reactor Cart

N. Center of Cart Deck

S. Center of Cart Deck

DATE: FEBRUARY 9, 1967

General Survey

0700

(139.7)

N. Edge of Reactor Cart

N. Top of Privy Roof

N. , Center of Cart Deck

80

S., Center of Cart Deck

82

Center of Nozzle at $1^{\prime}$

500

Reactor Midplane at $1^{\prime}$

2000

EP-III

DATE: FEBRUARY 10, 1967, Shutdown at 1315

Initial Survey \# 1

1400

1415

1445

Initial Survey \#2
1508

1515
Main Gate

$150^{\prime} \mathrm{W}$. of Reactor

250' S. of Reactor

RAM at West Wing Wall

$700^{\prime} \mathrm{W}$. of Reactor

$1000^{\prime}$ East

$480^{\prime}$ East

220' East

1000 ' North

$480^{\prime}$ North

220' North
30

1000

100

150

10

10

100

1000

10

100

1000 


\begin{tabular}{|c|c|c|c|}
\hline Monitoring Assignment & Time & Survey Location & $\begin{array}{l}\text { Dose Rate } \\
\mathrm{mR} / \mathrm{hr}, \quad O W \\
\end{array}$ \\
\hline \multirow[t]{9}{*}{ Rods Team } & 1509 & Steps to Basement & 26 \\
\hline & 1510 & For. Control Room & Bkgd. \\
\hline & 1513 & Reactor Pit & 1000 \\
\hline & 1514 & Outside Prop. Pump & \\
\hline & & Room & 280 \\
\hline & 1515 & Inside Prop. Pump & \\
\hline & $(2.0)$ & Room & 80 \\
\hline & 1516 & Hook-up Room & 8 \\
\hline & 1528 & Local Control Room (LCR) & 5 \\
\hline \multirow[t]{5}{*}{ J-5 Shutdown \#1 } & 1515 & Main Gate & 27 \\
\hline & 1516 & $10^{\prime}$ from LCR Door & 40 \\
\hline & 1600 & W. Door Flow Control & \\
\hline & & Room (FCR) & 280 \\
\hline & $\begin{array}{l}1601 \\
(2.8)\end{array}$ & Inside $\mathrm{FCR}$ & 75 \\
\hline \multirow[t]{6}{*}{ Special Survey } & 1549 & Borated $\mathrm{H}_{2} \mathrm{O}$ Tank & 200 \\
\hline & 1610 & Under Dewar \#2 & 300 \\
\hline & & Under Dewar \#1 & 120 \\
\hline & 1650 & Wire at $6 " 1$ & 100000 \\
\hline & 1700 & N.E. Gate & 180 \\
\hline & 1702 & R. R. Gate & 140 \\
\hline Car Leak Check & $\begin{array}{l}1612 \\
(3)\end{array}$ & $200^{\prime}$ E. of Reactor & 1000 \\
\hline \multirow[t]{2}{*}{ N-2 Wire Removal } & 1615 & $\mathrm{LN}_{2}$ Tank Farm, E. & 400 \\
\hline & $(3)$ & & 4000 \\
\hline \multirow[t]{4}{*}{ Air Conditioning Check } & 1635 & FCR Roof $5^{\prime}$ from Neut. & \\
\hline & $(3.2)$ & Door & 300 \\
\hline & 1637 & 12 "from Elephant Gun & 500 \\
\hline & 1641 & Vent Control Shed & 25 \\
\hline \multirow[t]{7}{*}{ J-5 Shutdown } & 1640 & Stairway to Electrical & \\
\hline & $(3.4)$ & Room (ELR) & 200 \\
\hline & 1642 & ELR & $<1$ \\
\hline & 1645 & Doorway to Propellant & \\
\hline & & Room & 200 \\
\hline & 1700 & In Propellant Room & 12 \\
\hline & 1715 & Under $\mathrm{H}_{2} \mathrm{O}$ Storage Tank & 400 \\
\hline \multirow[t]{3}{*}{ H-4 Dosimetry Removal } & 1700 & RAM, $20^{\prime}$ South & 660 \\
\hline & $(3.7)$ & W. Wing Wall, Unshielded & 10000 \\
\hline & & Reactor Pit, Top of Ladder & 800 \\
\hline \multirow[t]{3}{*}{ Rabbit Recovery } & 1710 & Tunnel Entrance & 80 \\
\hline & 1711 & Center of Tunnel & 600 \\
\hline & 1712 & $2 "$ from Rabbit Well & 25000 \\
\hline
\end{tabular}


Monitoring Assignmen

Core Photography
Time

2000

(6. 7)
Survey Location

FCR Roof-Center

Neut. Rm. Roof, behind Wall

Neut. Rm. -Periscope

Neut. Rm. -Gen'l Area
Dose Rate mR/hr. CW

100

2000

60

15

DATE: FEBRUARY 13, 1967

Reactor Shield

Bottom of Shield at $2^{2} \mathrm{~N}$.

Bottom of Shield at $2: \mathrm{E}$.

Bottom of Shield at $21 \mathrm{~W}$.

7000

Penthouse Wall, $3^{\prime}$ from

Igniter

3500

DATE: FEBRUARY 14, 1967

Shield Segment Check 0900

(93.3)

Bottom of Shield at $15^{\prime}$

500

Top of Shield at $10^{\prime}$

200

Top Lip of Shield 1' Below

440

Above Nozzle, Level with

Shield

50000

DATE: FEBRUARY 17, 1967, Full Power Run Scrubbed

Rods Team

0955

West Wing Wall

26

W. Shed Tracks

40

Privy Door

26

Privy, Inside

20

Dose Rate Lines

1408

$90^{\prime}$ E., W., \& N. of Reactor

10

$15^{\prime} \mathrm{E}$. \& W. of Reactor

100

$30^{\prime} \mathrm{N}$. of Reactor

100 
EP-IV

DATE - FEBRUARY 23, 1967, Shutdown at 1434

\begin{tabular}{|c|c|c|c|}
\hline Monitoring Assignment & Time & Survey Location & $\mathrm{mR} / \mathrm{hr}, \mathrm{OW}$ \\
\hline Initial Survey \# 1 & $\begin{array}{l}1723 \\
(2.8)\end{array}$ & $\begin{array}{l}1900^{\prime} \text { South } \\
950^{\prime} \text { South } \\
450^{\prime} \text { South } \\
\text { Main Gate } \\
2300^{\prime} \text { East } \\
1400^{\prime} \text { East } \\
800^{\prime} \text { East }\end{array}$ & $\begin{array}{r}10 \\
100 \\
1000 \\
700 \\
10 \\
100 \\
1000\end{array}$ \\
\hline DATE - FEBRUARY 24, & & & \\
\hline Rods Team & $\begin{array}{c}1000 \\
(19.4)\end{array}$ & $\begin{array}{l}\text { Dewar \#1, S. E. } \\
\text { Forward Control Room } \\
\text { Hook up Room, Max. } \\
\text { Hook up Room, Ave. } \\
\text { Top Steps of Basement } \\
\text { Shoe Covers @ 1", gamma }\end{array}$ & $\begin{array}{c}4000 \\
\text { Bkgd. } \\
200 \\
80 \\
2000 \\
2000\end{array}$ \\
\hline Photo Teams & $\begin{array}{c}1100 \\
(20.4)\end{array}$ & $\begin{array}{l}\text { W. Camera Bunker, Front } \\
\text { N. Camera Bunker, Front } \\
\text { N. Camera Bunker, Door } \\
\text { 700' North }\end{array}$ & $\begin{array}{r}60 \\
1400 \\
400 \\
900\end{array}$ \\
\hline $\mathrm{N}_{2}$ Pumping & $\begin{array}{c}1145 \\
(21.2)\end{array}$ & $\begin{array}{l}\text { S. ELR Entrance } \\
\text { Bottom of Stairs, ELR } \\
\mathrm{N}_{2} \mathrm{Fi} 11 \text { Sta. } \\
\text { LCR } \\
\text { Main Gate }\end{array}$ & $\begin{array}{r}40000 \\
600 \\
600 \\
12 \\
400\end{array}$ \\
\hline Elephant Gun Canisters & $\begin{array}{c}1300 \\
(22.4)\end{array}$ & $\begin{array}{l}\text { LN } 2 \text { Fill Sta., S. Pad Edge } \\
\text { S. Pump Room Door } \\
\text { N. Pump Room Door } \\
\text { Inside Pump Room } \\
\text { Hook up Room Inside, Ave. } \\
\text { Work Area by E. G. } \\
\text { Inside Neutronics Room Door } \\
\text { \#8 Canister, Contact }\end{array}$ & $\begin{array}{c}800 \\
2000 \\
4000 \\
2000 \\
80 \\
150 \\
350 \\
27000 / 8000 *\end{array}$ \\
\hline
\end{tabular}

* Open Window/Closed Window 


\begin{tabular}{|c|c|c|c|}
\hline Monitoring As signment & Time & Survey Location & $\begin{array}{l}\text { Dose Rate } \\
\mathrm{mR} / \mathrm{hr} \text {, OW }\end{array}$ \\
\hline Define Dose Lines & $\begin{array}{c}1530 \\
(24.9)\end{array}$ & $\begin{array}{l}1500^{\prime} \text { South } \\
600^{\prime} \text { South } \\
400^{\prime} \text { South }\end{array}$ & $\begin{array}{r}10 \\
100 \\
1000\end{array}$ \\
\hline \multicolumn{4}{|c|}{ DATE - FEBRUARY 25, 1967} \\
\hline Special Survey & $\begin{array}{l}1710 \\
(50.6)\end{array}$ & $\begin{array}{l}\mathrm{LN}_{2} \text { Fill Station } \\
\text { Top of Steps to Basement } \\
\text { Middle Landing to Basement } \\
\text { Bottom Landing to Basement }\end{array}$ & $\begin{array}{r}200 \\
2500 \\
2000 \\
200\end{array}$ \\
\hline \multicolumn{4}{|c|}{ DATE - FEBRUARY 27, 1967} \\
\hline Core Photography & $\begin{array}{c}0400 \\
(61.4)\end{array}$ & $\begin{array}{l}\text { Neutronics Roof } \\
\text { Neutronics Room Door Closed } \\
\text { Neutronics Room Outer Door } \\
\text { Open } \\
\text { On Ladder to Neutr. Room }\end{array}$ & $\begin{array}{r}2000 / 8000 \\
10 \\
1000 \\
400\end{array}$ \\
\hline Rods Team & $\begin{array}{c}1025 \\
(67.8)\end{array}$ & $\begin{array}{l}\text { W. of Motor Drive Bldg. } \\
\text { Top of Steps to Basement } \\
\text { Mid-Landing to Basement } \\
\text { Bottom Landing to Basement } \\
\text { Outside W. Door, Propellant } \\
\quad \text { Pump Room } \\
\text { Inside Propellant Pump Room }\end{array}$ & $\begin{array}{r}9 \\
1800 \\
1000 \\
74 \\
240 \\
16\end{array}$ \\
\hline Flow and Pump Room & $\begin{array}{l}1400 \\
(71.4)\end{array}$ & $\begin{array}{l}\text { Pump Room, Doors Closed } \\
\text { S. Pump Room Door, Outside } \\
\text { Particles Outside Pump Room } \\
\text { Double Doors @ 2" }\end{array}$ & $\begin{array}{c}30 / 100 \\
200 \\
20000 / 6000 *\end{array}$ \\
\hline \multicolumn{4}{|c|}{ DATE - FEBRUARY 28, 1967} \\
\hline Water Team & $\begin{array}{l}0700 \\
(88.4)\end{array}$ & $\begin{array}{l}\text { Enroute to Neutronics Room } \\
\text { Water Storage Tank Area }\end{array}$ & $\begin{array}{r}400 \\
20\end{array}$ \\
\hline Photo Team & $\begin{array}{c}0900 \\
(90.4)\end{array}$ & $\begin{array}{l}\text { N. Bunker, Door } \\
\text { N. Bunker, Front }\end{array}$ & $\begin{array}{l}20 \\
25\end{array}$ \\
\hline
\end{tabular}


Monitoring Assignment

$\mathrm{N}_{2}$ Pumping

Reactor Radiation

Measurements

General Survey

DATE - MARCH 1, 1967

General Survey

(125. 1)
Survey Location

Compressor Room, S.

Motor Drive Bldg, Front

Pump Room Entrance

Pump Room Inside

FCR, S. Entrance

CEL Inside

CEL-FCR Catwalk, Above

CEL-FCR Catwalk, Below

Bottle Area

$\mathrm{N}_{2}$ Dewar Area, Avg.

$\mathrm{N}_{2}$ Dewar Area, Max.

Nozzle, 2' Above

Vessel, Center \& Contact

Nozzle Throat at $2^{\prime}$

FCR Center

Smear

FCR Roof, N. End

Smear

Prop Pump Roof, Top of Stairs

Prop Pump Roof, S. End Smear

Prop Pump Roof, Center Smear

Neutronics Roof, Center, Smear
Dose Rate $\mathrm{mR} / \mathrm{hr}, \mathrm{OW}$

30

150

65

15

20

200

800

9000

250

25

60

$2,250,000$

$13,500,000$

$3,750,000$

500

$5 / 35$

8000

$5000 / 20,000$

2500

1000

$10 / 20$

2500

$5 / 10$

10,000

$35 / 3000$

FCR Roof, Center

DATE - MARCH 2, 1967

Camera Bunker

1500

(144. 4)

Penthouse Roof

500

General Survey

2245

(152.1)
N. Camera Bunker, Front

FCR Roof, Center

650

Penthouse Roof

400

S. Dewar, W. Side Pad

Drain and Curb, S. W.

Dewar Pad 
Monitoring Assignment $\quad$ Time $\quad$ Survey Location

DATE - MARCH 3, 1967

Decon

1000

$(163.4)$

DATE - MARCH 6, 1967

General Survey

0830

1030

DATE - MARCH 7, 1967

General Survey

1245

(238. 1)

DATE - MARCH 10, 1967

Reactor Shield

(Bottom 1/4)
0100

(346. 4)
E. Section:
LCR, Outside

FCR Roof Center

FCR Roof, Center
Dose Rate $\mathrm{mR} / \mathrm{hr}, \mathrm{OW}$

LCR, Outside, Avg.

10

12,000

20,000

80

120

Center Concave Side at Contact

Center Concave Side at

1 Meter

Center Convex Side at

Contact

Center Convex Side at

$$
1 \text { Meter }
$$

Bottom of Shield

4000

3000

800

800

1000

W. Section:

Eenter Conclave Side at Contact with T/C

Concave Side at 1 Meter

Convex Side at Contact

Convex Side at 1 Meter

70,000

13,000

1700

1000

DATE - MARCH 14, 1967

Shield Removal from

0950

Rx Pad

(451.2)

Uncouple and Rig Lift

Fixture

4000 


Monitoring Assignment
Shield Removal from
Rx Pad (cont.)
Photograph Shield

Time

Survey Location

Guide and Put Water Shields

Crane $\mathrm{Cab}$ on Car

Train Cab

1315

(456)
Dose Rate $\mathrm{mR} / \mathrm{hr}, \mathrm{OW}$

1000

250

850

450

900 